\title{
New Firm Formation and Employment Growth: Regional and Business Dynamics
}

\author{
Rui Baptista \\ Department of Engineering and Management and IN+ Centre for Innovation, \\ Technology and Policy Research, Instituto Superior Técnico, Technical University of \\ Lisbon \\ Av. Rovisco Pais, 1049-001 Lisbon, Portugal \\ and \\ Department of Social and Decision Sciences \\ Carnegie Mellon University \\ 5000 Forbes Avenue, BP 208, Pittsburgh, PA 15217 \\ and \\ Max Planck Institute of Economics \\ Kahlaische Strasse 10, D-07745 Jena, Germany

\section{Miguel Torres Preto} \\ IN+ Centre for Innovation, Technology and Policy Research, Instituto Superior \\ Técnico, Technical University of Lisbon \\ Av. Rovisco Pais, 1049-001 Lisbon, Portugal
}

\begin{abstract}
This study examines differences in the effects of start-up rates on subsequent employment change. Two sources of such differences - types of start-ups and types of regions - are analyzed. We find that differences between types of start-ups - namely between knowledge-based and other firms - dominate differences in regional agglomeration. In particular, differences in the effects of new start-ups on subsequent employment growth between more agglomerated and less agglomerated regions are greater for knowledge-based start-ups than for other types of start-ups. The results suggest that, while knowledge-based start-ups are likely to impart greater benefits on future employment than other types of start-ups, these benefits are greater when those start-ups locate in more agglomerated regions.
\end{abstract}

Keywords: Entrepreneurship; Employment Growth; Knowledge based firms; Regional Agglomeration

J.E.L. Classification: J23, M13, O52

Corresponding Address: Miguel Torres Preto, IN+ Centre for Innovation, Technology and Policy Research, Instituto Superior Técnico, Av. Rovisco Pais, 1049-001 Lisbon, Portugal. Tel: +351.218.417.379. Fax: +351.218.496.156. E-mail: miguel.preto@ dem.ist.utl.pt . 


\section{Introduction}

Economic analysis has increasingly focused on the economic benefits of entrepreneurship, in terms of, for instance, employment generation or innovations (van Praag and Versloot, 2007). A recent stream of studies has examined whether there is a positive relationship between increases in new firm formation rates and subsequent employment growth at the regional level. These studies have shown that the impact of new business formation on regional development is distributed over a relatively long period of time, usually ten years (less than ten years are taken if the time series is not long enough). Comparable patterns of results were found for Germany (Fritsch and Mueller 2004, 2008); Great Britain (Mueller, van Stel and Storey 2008); the Netherlands (van Stel and Suddle, 2008); Portugal (Baptista, Escária and Madruga 2008; Spain (Arauzo-Carod, Liviano-Solis and Martin-Bofarull 2008); and the US (Acs and Mueller, 2008).

New firms are generally smaller than the average incumbent, and their direct contribution to the stock of jobs in an economy is relatively small (Van Stel and Storey, 2004). Moreover, new businesses have a greater probability of failure than old businesses. According to Geroski (1995), the survival probability of most entrants is low and successful entrants may take more than a decade to achieve a size comparable to that of the average incumbent. It is therefore striking that a key finding shared by the aforementioned stream of studies for different countries is that there is a positive relationship between new firm formation and subsequent employment growth. These studies found a similar pattern for the lag structure of the effects of new firm formation on employment growth over time. First, the magnitude of direct employment creation in entry cohorts was found to be small. Second, new entrants subsequently crowd out inefficient firms, lowering employment. Third, positive supply-side effects increase overall employment significantly, through the growth of successful entrants and incumbents.

The remarkable similarity in the patterns of results observed across countries suggests that there are three different kinds of impacts of new firm formation on subsequent employment change, and that these impacts do not occur simultaneously, but in different points in time.

i. First, a direct impact of employment creation by firm $j$ in time $t$ is observed; 
ii. Second, there is a period when displacement of existing jobs occurs, possibly as a result of increased competition and market selection;

iii. Third, there are positive long term impacts, possibly associated with increased competitiveness and innovation brought about by successful new firms that spills over to the industry.

Even though patterns of effects of new business formation on employment growth are similar across countries, there seem to be pronounced differences in the magnitude and specific timing of these effects. Moreover, differences across regions within countries are also observed (Fritsch and Mueller, 2008). Such differences are significant even when one controls for different regional industrial structures. ${ }^{1}$ This finding suggests that, even when one controls for economic structure, different regions display different kinds of industrial dynamics, and attract different kinds of new firms.

In particular, the studies by Acs and Mueller (2008) and Fritsch and Mueller (2008) revealed pronounced differences in the magnitude and timing of the effects of new firm creation on subsequent employment growth across regions within countries. In their study for the US, Acs and Mueller (2008) find that large consolidated metropolitan areas are fertile ground for the growth of new businesses, whereas small towns and cities may register high rates of new firm entry but cannot support the expansion of rapidly growing firms.

Similar disparities exist across different countries. Baptista, Escária and Madruga (2008) find that the positive long term impacts of new firm formation on subsequent employment growth in the case of Portugal are smaller and take longer to occur than the same kind of effects in the comparable case of Germany, as found by Fritsch and Mueller (2004). As these studies controlled for differences in regional industrial structures, such disparities are likely due either to differences in business dynamics (i.e. the qualities of the new firms being started) or to differences in regional/national characteristics that may bolster the positive long term impacts of new firm creation on employment growth.

\footnotetext{
${ }^{1}$ Economic activities in different regions differ accordingly to their composition in terms of sectors; therefore, regions with greater proportions of firms in declining sectors should display lower impacts of new firm formation on employment growth than regions with a greater proportion of firms in growing sectors. A shift-share correction procedure was used to correct for this kind of difference in, for instance, instance, the studies by Baptista, Escária and Madruga (2008); and Mueller, van Stel and Storey (2008). Differences across regions in the effects of new firm formation on employment growth remained significant.
} 
The present paper uses data for Portugal to examine in detail how differences in regional and business dynamics may contribute to generate disparities among regions in the magnitude and timing of employment growth effects. In particular, we examine differences between the long-term effects on employment growth of new firm creation in knowledge-based sectors and in other sectors for regions with different levels of productivity and agglomeration of economic activity.

The paper proceeds as follows. The next section provides a brief exploration of the regional and business dynamics that may lead to differences in the magnitude and timing of the long term effects of new business formation on employment growth within and across regions. Section 3 focuses on the empirical analysis. Section 4 presents and discusses the results, and section 5 provides some concluding remarks.

\section{Effects of New Firm Formation on Employment Growth: Regional and Business Dynamics}

The relationship between new firm entry and economic growth has been addressed by recent theory and empirical work. Acs et al. (2004) argue that entrepreneurship (i.e. new firm creation) contributes to economic growth by penetrating the "knowledge filter" that prevents new knowledge from spilling over to economic agents. In this way, new firm creation facilitates the working of the fundamental mechanism behind sustained economic growth (Romer, 1986, 1990). Recent empirical studies have found a positive relationship between new firm entry and productivity growth (Disney, Haskel and Heden, 2003; Aghion et al., 2004).

While the creation of new firms may play a significant role in spawning regional economic growth, the extent of the effects of entrepreneurial activity on subsequent growth should vary across regions according to the pools of innovative opportunities and human capital available in each region (Shane, 1996; Baptista and Mendonça, 2009). Business and regional dynamics are strongly inter-related, and play an important role in determining the impact of new firm entry on economic development and employment growth. Regions may differ considerably with regard to the characteristics of new and incumbent businesses as well as with regard to their ability to absorb the positive effects of new business formation. In order to analyze such differences, they distinguish between types of regions according to different criteria, including the degree of 
agglomeration and the average labor productivity. Acs and Mueller (2008) look at differences in levels of business dynamics (i.e. proportion of rapidly growing firms) between regions; not surprisingly, they find that most of these rapidly growing firms are located in the larger (i.e. more agglomerated) metropolitan regions. ${ }^{2}$ It seems therefore reasonable to assume that there is a positive relationship between regional/local agglomeration and business dynamics levels. ${ }^{3}$

The role played by agglomeration effects - or externalities - in bolstering supplyside spillovers has been widely addressed by several streams of literature (see, for instance, Baptista, 1998; and Audretsch, 2003). There is a general belief that location matters to the development and growth of industries. Much literature has been developed around the notion that firms tend to concentrate in certain regions so they can benefit from co-location. Feldman (1994) argues that spillovers associated with innovation are stronger within relatively restricted geographical regions due to agglomeration externalities that increase the capacity of firms to tap into the local pool of new ideas, while Jaffe, Henderson and Trajtenberg (1993) provide evidence of geographical concentration of spillovers on innovative (patenting) activity; Baptista (2000) finds that the probability of a firm adopting an innovation depends positively on the local density of other adopters.

Other studies have argued that agglomeration externalities influence business dynamics directly through the process of displacement that determines which firms survive and grow, and which firms fail (Acs and Mueller, 2008). Agglomeration externalities influence firm competitiveness and growth through mechanisms that involve both concentration and diversity of industries (Glaeser et al., 1992; Blien, Südekum and Wolf, 2006), and may also result from efficiency gains due to increased competition: several empirical studies support the conjecture of a relatively high level of competition in agglomerations. These studies find higher rates of start-ups (Fritsch and Falck, 2007) and a lower probability of survival (Fritsch, Brixy and Falck, 2006) in more agglomerated regions.

Baptista, Escária and Madruga (2008) suggest that a substantial part of the differences across regions and countries in the size and structure of lagged effects of

\footnotetext{
${ }^{2}$ According to Acs and Mueller (2008), 40 percent of all the rapidly growing firms are located in only 20 metropolitan regions, which are mostly the largest cities in the United States.

${ }^{3}$ Glaeser et al. (1992) found a positive correlation between agglomeration externalities and firm growth levels.
} 
entry on employment change are likely to be due to differences in types and/or qualities of start-ups. The size of negative (market selection) and positive (supply-side spillovers) effects and the lag time for those effects to ensue should vary according to the type of entrant, as not all entrants are equally efficient and/or innovative, and therefore not all have the same impact. While it is acknowledged that the emergence of positive supplyside effects from new firm formation does not require that newcomers are successful, ${ }^{4}$ it is expected that different kinds of start-ups will have different impacts on the industrial re-structuring process according to the "quality" of new entrants with regard to innovation, efficiency, and product differentiation. ${ }^{5} \mathrm{New}$ firms provide a vehicle for the introduction of innovations into an economy, therefore being a source of both industry turbulence (Beesley and Hamilton, 1984) and productivity growth (Aghion et al., 2004). ${ }^{6}$

Even though, as pointed out by Van Stel and Storey (2004), innovation in new firms seems to be not as frequent as expected, a significant contribution by new entrants to employment growth occurs through increased competitiveness and enhanced efficiency of incumbents. In a recent study for Germany, Fritsch and Noseleit (2009) find that the employment effects of new businesses on the incumbents are significantly positive and considerably larger than the employment that is directly generated in the start-ups.

When discussing the transition from the managed economy to the entrepreneurial economy, Audretsch and Thurik (2004) stress the role played by the increasing pace of technological progress. In the managed economy technological trajectories were relatively well-defined and firms were subject to relatively low uncertainty, while in the entrepreneurial economy product life-cycles are short and competitive conditions change rapidly. In a meta-analysis of the empirical evidence that net employment growth is generated by only a few rapidly growing firms, Henrekson and Johansson (2008) do not find that these firms are disproportionately high tech. However, the large

\footnotetext{
${ }^{4}$ Hoetker and Agarwal (2007) find that significant diffusion of knowledge may occur after an innovative firm exits an industry if other firms are able to use that firm's activities as a template to successfully replicate and extend its innovative knowledge.

${ }^{5}$ Baptista and Preto (2009) sought to examine the effects on employment growth of start-up rates according to different types of entrants (e.g. small versus large start-ups or domestics vs. foreign startups).

${ }^{6}$ Disney, Haskel and Heden (2003) find that in the UK between 1980 and 1992 about half of productivity gain was because of internal factors, such as introducing new technology and organisational changes. The remaining half was because of external factors most notably that the entrants were more productive than those exiting. However amongst single plant independent firms almost all the gains were attributable to external factors.
} 
majority fits in the less restricted qualification of knowledge-based enterprises (KBEs). ${ }^{7}$ A greater presence of knowledge-based entrants is likely to boost the introduction of innovations in the market. Knowledge-based industries tend to have shorter product and technology life-cycles and, being less focused on operational economies of scale, provide more opportunities for new, small firms to induce market re-structuring and change through innovation and efficiency improvements. It can therefore be argued that both employment destruction (due to increased competition and displacement) and employment creation (due to positive supply-side spillovers) will be greater the higher is the rate of entry in knowledge-based sectors.

\section{Empirical Analysis}

Our study investigates whether there is a significant relationship between new firm start-up rates and subsequent employment growth at the regional level using longitudinal data for Portuguese regions. Following Fritsch and Mueller (2004, 2008), we look at the lag structure of these effects and at the total effect over time. Based on the discussion in the previous section, as well as on Fritsch and Mueller (2008), and Acs and Mueller (2008), two main hypotheses are analyzed:

Hypothesis 1: increases in the start-up rates of knowledge-based enterprises will have a greater impact on subsequent employment change than increases in the start-up rates of other firms, regardless of the level of agglomeration/business dynamics in the region.

Hypothesis 2: increases in start-up rates will have stronger impacts on subsequent employment change in regions with higher levels of agglomeration/business dynamics, as measured by the density of economic activity, as well as productivity.

\subsection{Data and measurement issues}

Data on entry and employment come from the longitudinal matched employeremployee micro-data set Quadros de Pessoal (QP), which was built based on information gathered in annual mandatory surveys by the Portuguese Ministry of Labor

\footnotetext{
${ }^{7}$ This classification includes high technology and medium-high technology industries, post and communications, finance and insurance and business services (OECD, 2002).
} 
and Social Solidarity. These surveys cover all business units with at least one wageearner in the Portuguese economy. ${ }^{8}$

Following Fritsch and Mueller (2004), and Baptista, Escária and Madruga (2008) we use as indicator of regional development the relative change over a two-year period of employment in the private sector. By using changes over a two-year period we attempt to avoid disturbances due to short-run fluctuations. The specific form in which the data set was built enables us to distinguish between true start-ups and entry of new plants/business units. New firm formation is measured by yearly regional start-up rates. Start-ups were assigned to the 30 standardized (NUTS 3) regions of Portugal for the period 1983-2000. Start-ups in the agricultural sector are excluded.

In order to control for differences in the size of regions, entry rates are measured relative to regional dimension. Following Ashcroft, Love and Malloy (1991), the regional size denominator controls for different absolute sizes of regions. Following Garofoli (1994), and Audretsch and Fritsch (1994), regional start-up rates are measured using the size of the regional workforce as denominator ("labor market" approach). This methodology has advantages over the use of the total number of firms in a region as the denominator ("business stock" approach) since the latter might be misleading in regions with a few large firms (in such case, small numbers of new firms would provide an artificially high birth rate, primarily because of the small denominator).

\subsection{Knowledge-based start-ups, regional agglomeration, and economic performance}

In our analysis, we follow the OECD classification of knowledge-based sectors, aggregated by technology level (OECD, 2002). This is a very wide definition of technology-intensive sectors, encompassing high and medium technology industries, as well as knowledge-based services. Using this wide definition of technology intensity provides a more adequate measure of the business dynamics in a region than merely including entry in high tech industries, as these firms represent a very small share of the Portuguese industrial structure, and are therefore unlikely to impact significantly on regional innovation and efficiency levels.

\footnotetext{
${ }^{8}$ The database is property of the Portuguese government and can be accessed on-site at the Observatory of the Ministry of Labor and Social Solidarity.
} 
In order to measure regional agglomeration effects and business dynamics, we follow both Fritsch and Mueller (2008), and Acs and Mueller (2008). While the former study use population density as a proxy for the level of agglomeration externalities in German planning regions, classifying these into "highly agglomerated," "moderately congested; and "rural," the latter paper looks at levels of business dynamics in American metropolitan regions by measuring the shares of fast growing and slow growing firms.

Acs and Mueller (2008) revisit one of the main insights of David Birch's (1981) seminal contribution about the role played by small firms in employment creation: the perception that a small number of rapidly growing establishments (so-called "gazelles") are responsible for most of the employment growth in regional economies. These authors find that some regions - the more agglomerated metropolitan areas - have most of the rapidly growing companies. By contrast, less agglomerated regions, have a predominance of slow growing companies.

Table A1 (in the Appendix) shows that, in the particular case of Portugal, it is easy to identify highly agglomerated regions as the ones generating greater entry. As can be seen on Figure A1, only the large metropolitan regions of Greater Lisbon and Greater Oporto (NUTS III codes 10104 and 10302 in Table A1) display agglomeration levels that are susceptible of ranking in the German "highly agglomerated" group defined by Fritsch and Mueller (2008). Moreover, these two regions are also the ones that display higher entry rates. Hence, we start by classifying the 30 Portuguese NUTS 3 regions into two groups:

i. Highly agglomerated regions, corresponding to the metropolitan regions of Greater Lisbon and Greater Oporto, which are highly agglomerated and display high proportions of rapidly growing new firms (i.e. high levels of business dynamics);

ii. Modestly agglomerated regions, corresponding to all other 28 NUTS regions, which display below average levels of agglomeration and business dynamics.

The QP database allows us to use start-up and incumbent sizes to determine the proportions of rapidly growing start-ups per region. In order to compute regional population density, additional data on NUTS regions was gathered from the Portuguese National Institute of Statistics (INE).

In order to look closer at the business dynamics of modestly agglomerated regions i.e. the ones displaying relatively low levels of agglomeration and start-up rates, and 
lower than average proportions of rapidly growing firms, we follow Fritsch and Mueller (2008) and look at differences in labor productivity, as measured by GDP per working population. When drawing a distinction between regions according to their economic performance (i.e. labor productivity), these authors find that the differences between the effects of new business formation on employment are much more pronounced between higher and lower productivity regions than when regions are differentiated on the basis of agglomeration only. However, Fritsch and Schroeter (see the present special issue) find that the main determinant of this effect is population density rather than labor productivity. Many of the German high productivity regions have high levels of population density while most of the low productivity regions are rural areas.

By examining the differences in the effects of new business formation on employment between regions with high and low labor productivity, we observe whether increases in entry rates in regions with a high proportion of slow growing firms but relatively high levels economic performance (as measured by labor productivity) have a greater impact on subsequent employment change than in regions with a majority of slow growing firms and low economic performance. While regions with high economic performance and slow growing firms may be dominated by efficient incumbents in mature industries, employing better qualified human capital (from which the founders of new firms are likely to be drawn), regions with slow growing firms and low economic performance are likely to be dominated by less efficient incumbents, employing less qualified human capital. Firms founded by less qualified human capital are likely to have a lower impact on the business dynamics of a region and, therefore, a lower impact on subsequent employment growth, whether through enhanced efficiency or through amplified innovation.

\subsection{Econometric Methodology}

The basic relationship to be modeled is adapted from Baptista, Escária and Madruga. (2008), where the change in regional employment between period $t$ - 2 and period $t$ is explained by the firm birth rates in periods $t, t-1, t-2 \ldots n$, and has the following form:

$$
\begin{aligned}
& \Delta E M P_{t, r}=\left[\alpha_{0 . B I R_{t . r}^{I}}^{I}+\alpha_{1 .}^{I} B I R_{t-1, r}^{I}+\ldots+\alpha_{n \cdot}^{I} B I R_{t-n, r}^{I}\right]+\left[\alpha_{0 . B I R_{t, r}^{I I}}^{I I} \alpha^{I I} .\right. \\
& \left.B I R_{t-1, r}^{I I}+\ldots+\alpha_{n}^{I I} . B I R_{t-n, r}^{I I}\right]+X_{t, r} \beta+\varepsilon_{t}
\end{aligned}
$$


Where $\triangle E M P_{t, r}$ is the change in regional employment between period $t-2$ and period $t$ for region $r ; B I R_{t-i, r}^{I}, B I R^{I I-i, r}$ are the firm birth rates in period $t-i$ for type $I$ and type $I I$ start-ups (e.g.: type $I$-knowledge-based firms; type $I I$-other firms), with $i=0, \ldots, n$ being the lag periods considered for region $r$; and $X_{t, r}$ are the control variables. For the present study, yearly start-up rates at the beginning of the current employment change period and for the ten preceding years are included.

However, an additional problem arises due to the significance of path dependency of regional new firm formation over time. We find that there is persistency of new firm formation over time at the regional level. The start-up rate in period $t$ is significantly correlated with the start-up rate in the previous year and is also significantly determined by new firm formation activity five, ten and 15 years previously. The initial strong pattern of path dependency weakens over time. Almost $50 \%$ of the variation of the startup rate in $\mathrm{t}$ can be explained by new firm formation activity 1, 5, 10 and 15 years previously. ${ }^{9}$ This means that correlations between start-up rates over time are mostly significant, leading to multicolinearity that makes interpretation of coefficients in the models difficult. In order to deal with this problem, the lag structures for the effect of regional start-up rates on regional employment growth are estimated using Almon polynomials (see Trivedi, 1978; and Van Stel and Storey, 2004, for details). The Almon lag procedure reduces the effects of multicolinearity in distributed lag settings by imposing a particular structure on the lag coefficients. In the Almon method, parameter restrictions are imposed in such way that the coefficients of the lagged variables are a polynomial function of the lag. In this way, the start-up rate coefficients are reparameterized "smoothly."

When estimating the effects of start-up rates in different types of sectors (knowledgebased and others), we are introducing additional sources of bias, as residuals become correlated over time and heteroskedasticity becomes more significant. While studies such as Fritsch and Mueller (2004) and Baptista, Escária and Madruga (2008) used Huber-White robust estimators, under the new circumstances, we find that the Feasible Generalized Least Squares (FGLS) estimator corrects for AR(1) serial correlation specific to each panel and is also appropriate to deal with heteroskedasticity, since it handles cross-sectional correlation equally well (Parks, 1967; Beck and Katz, 1995).

\footnotetext{
${ }^{9}$ Tables containing the correlations of new firm entry over time are omitted due to space concerns, and are available from the authors upon request.
} 
In order to check the results from the FGLS estimation, we also use other estimation using panel corrected standard errors - robust fixed effects. It can be argued that in this case this estimation approach could be more efficient given to the data structure required to perform the former estimation technique. ${ }^{10}$ The results obtained are quite similar to those for FGLS, so only the estimations for FGLS are displayed. ${ }^{11}$

Control variables are used to account for effects specific to country-level business cycles and to region-specific effects that are not corrected for by the shift-share procedure. ${ }^{12}$ Estimation of region-specific fixed effects is expected to capture regional asymmetries including differences in local labor market conditions, house prices and the extent of knowledge/innovation spillovers, as well as different cultural attitudes towards entrepreneurship - regions may differ in how they favor entrepreneurial activity and how they react to business failure.

Two control variables are included in estimation, namely population density and average size of the firms. The objective of incorporating population density (number of inhabitants per square $\mathrm{km}$ ) in our models is to control for regional characteristics which might affect the relationships between new firm formation and employment change. Fritsch and Mueller (2008) argue that regional population density is highly correlated with a number of factors such as the wage level, real estate prices, quality of communication infrastructure, qualification of the workforce, and diversity of the labor market. By incorporating the regional average firm size we are controlling for regional market structure, and intensity of regional competition.

Model estimations also correct for spatial autocorrelation. Following Anselin (1988), and Anselin and Florax (1995), the average of the residuals in adjacent regions is

\footnotetext{
${ }^{10}$ Total number of temporal observations must be as large as the total number of panels (Beck and Katz, 1995). In this case we have a panel of 18 years with 30 regions which could not be the most appropriate for this technique.

${ }^{11}$ The results for the panel corrected standard errors (omitted from the paper due to space constraints) are available from the authors upon request.

${ }^{12}$ The relative importance of incumbents and start-ups varies systematically across both regions and industries. For example, start-up rates are systematically higher in services than in manufacturing. Entrepreneurial activity could be systematically overestimated in regions with a high share of industries where start-ups play an important role, while the role of new firm formation in regions with a high share of industries where start-ups are relatively few would be underestimated. To account for differences in industrial structures and in the relative importance of start-ups and incumbents across industries, a shiftshare procedure (Ashcroft et al. (1991); Audretsch and Fritsch 2002) is applied in order to derive a measure of sector-adjusted start-up activity. The shift-share measure adjusts the raw data by imposing the same industry composition in each region. Thus, the sector-adjusted number of start-ups is defined as the number of new firms in a region that can be expected to be observed if the composition of industries was identical across all regions (see a detailed description of this method in Baptista et al. 2008).
} 
included in the estimation. These residuals provide an indication of unobserved influences that affect larger geographical entities than NUTS3 and that are not entirely reflected in the explanatory variables. ${ }^{13}$

\section{Results}

Results are presented in Tables 1-6 and Figures 1-6. We begin by examining differences in the impact of new firm formation on subsequent employment growth between the highly agglomerated regions - Greater Lisbon and Greater Oporto - and other regions, as displayed by Tables 1-3 and Figures 1-3. Table 1 and Figure 1 present the effects of the total start-up rate on subsequent employment change in highly agglomerated vs. other regions. Table 2 and Figure 2 display the results for the same two kinds of regions when only knowledge-based firms are considered. Table 3 and Figure 3 present the results when the effects of the start-up rates for knowledge-based firms and other firms are estimated simultaneously for each type of region.

Results are presented for the unrestricted and restricted (Almon polynomial lag) models. Estimation of the Almon polynomial lag model assumes that the effect of changes in yearly start-up rates is distributed over eleven periods ( $t$ to $t-10)$. Almon lag models were estimated for the second through to the fifth orders. A critical issue in applying the Almon lag procedure is determining which order of polynomial to consider. $^{14}$

As can be seen in Figures 1-3, the patterns of effects of new business formation on employment change are different for highly agglomerated and modestly agglomerated regions. New firm formation in highly agglomerated regions initially has a negative effect, suggesting that displacement effects occur rapidly upon entry of new firms. The direct effect of new business formation in other regions is generally positive. In highly agglomerated regions, however, positive effects of new firm creation on employment

\footnotetext{
${ }^{13}$ Estimations showed spatial autocorrelation to be insignificant, therefore not affecting the coefficients for the other variables. To correct for this, following Fritsch and Mueller (2004), we compute for each region the average of the residuals in the neighbouring regions and include this variable as an explanatory variable in the model.

${ }^{14}$ An appropriate way to do this is to use Likelihood Ratio tests. Comparing the Nth order Almon polynomial model with the $(\mathrm{N}+1)^{\text {th }}$ order Almon polynomial model comes down to a Likelihood Ratio test with one restriction, since each additional order of the polynomial adds one restriction to the model. In the present case, we find that the 4th order polynomial provides the best fit for the lag structure of the effects of new firm formation on regional employment change in each of the cases under analysis, so we present the estimation results for that model.
} 
change become dominant after the second year, and their magnitude is higher than that of positive indirect effects in other regions. In both cases, the effect tails off from the sixth year onwards.

The pattern of effects when only knowledge-based firms are considered is somewhat different. Knowledge-based firms seem to play a more significant role in business dynamics and displacement effect than other firms, since negative selection effects occur both in gazelle and modestly agglomerated regions, and the decline in total employment goes on until the third period. Only after that do positive spillovers become dominant. These effects are much stronger for highly agglomerated regions, making for a clearly positive overall effect on total employment.

When the effects of the start-up rates for knowledge-based firms and other firms are estimated simultaneously for highly agglomerated and modestly agglomerated regions (Table 3 and Figure 3) the pattern of results suggests that the type of start-up (knowledge-based vs. other firms) plays a more important role in stimulating displacement and indirect positive spillovers than the type of region. Knowledge based start-ups have an initial negative effect on employment change, followed by significant, positive indirect effects occurring from the fourth (gazelle regions) and fifth (other regions) periods onwards. The overall effect on knowledge-based start-ups seems to be clearly positive regardless of agglomeration levels and regional business dynamics while the overall effects of other types of start-ups appear not to be significant.

It seems therefore that Hypothesis 1 (differences in type of start-up) plays a more important role in explaining variations on the impact of new business formation on subsequent employment growth than Hypothesis 2 (differences in the type of region). In fact, while the overall effect of start-up rates on employment growth appears to be clearly greater in highly agglomerated regions than in other regions when knowledgebased start-ups are concerned, the same conclusion cannot be clearly drawn for other types of start-ups. This suggests that the creation of knowledge-based firms imparts greater positive indirect effects on employment change in regions with high levels of agglomeration and business dynamics. The same is not clearly true for start-ups that are not knowledge-based. This is possibly due to the fact that start-ups in these sectors are likely to be less innovative, so other firms have less to gain from spillovers.

In order to shed further light on the nature of regional dynamics, we look more closely at the economic performance of modestly agglomerated regions, differentiating 
between those with relatively high labor productivity (upper quartile) and those with relatively low labor productivity (lower quartile). Table 4 and Figure 4 present the effect of the total start-up rate on subsequent employment growth in high labor productivity and low labor productivity regions. Table 5 and Figure 5 display the results for the same two kinds of regions when only knowledge-based firms are considered. Table 6 and Figure 6 present the results when the effects of the start-up rates for knowledge-based firms and other firms are estimated simultaneously for high labor productivity and low labor productivity regions.

While differences in the effect of total start-ups on subsequent employment change between higher and lower labor productivity regions are not large, the pattern of effects again appears to suggest that more dynamic (i.e. productive) regions experience stronger effects of noisy selection and subsequent positive spillovers. The difference becomes clearer when we focus our analysis exclusively on knowledge-based start-ups Comparing Figure 5 with Figure 4 we see that, when only knowledge-based start-ups are considered, negative selection effects occur immediately after entry in higher productivity regions, while positive indirect effects become dominant after only two years. When all start-ups are considered, positive indirect effects occur after three years for higher productivity regions. In any case, the overall effect of knowledge-based startups on subsequent employment growth is clearly greater than that of other types of start-ups for both kinds of regions.

Table 6 and Figure 6 present the effects of the start-up rates for knowledge-based start-ups and other firms for high labor productivity and low labor productivity regions and confirm our previous observation that the type of start-up plays a more important role than the type of region when determining the effects of new business formation on subsequent employment growth. In both higher and lower labor productivity regions the negative displacement effects and positive indirect spillover effects are of greater magnitude for knowledge-based start-ups than for other types of start-ups. The pattern of the effects requires some interpretation, however. In lower productivity regions, the negative selection effect that originates from increases in the entry rate of knowledgebased start-ups is very strong indeed, and goes on until after the fifth year after entry. This is possibly due to the fact that new firms represent a significant efficiency improvement over existing firms in low economic performance regions, and their entry brings about the displacement of incumbents and the concomitant increase in 
unemployment. The overall efficiency gain means that, while there are significant positive indirect effects, the overall effect on employment change is not clearly positive. Selection effects brought about by knowledge-based entrants in higher labor productivity regions are of less magnitude, and occur earlier, after the third year.

Table 7 presents the sum of coefficients of the 11 periods under analysis for all models estimated, taken as an approximation of the overall effect of new firm formation on subsequent employment growth (following the approach taken by Fritsch and Mueller, 2008). The sums of the regression coefficients for both the unrestricted models and the fourth order Almon polynomial lag models confirm that the type of start-up plays a more important role in explaining differences in noisy selection and indirect spillover effects across regions than differences in agglomeration and economic performance between regions.

Focusing on the results of the Almon lag estimation, it is possible to observe on Table 7 that knowledge-based start-up rates have an overall positive effect on employment growth in the years after entry in both highly agglomerated and modestly agglomerated regions. When modestly agglomerated regions are divided according to economic performance, the overall positive effect of knowledge-based entry is positive in high economic performance (i.e. high labor productivity) regions, but negative in low labor productivity regions, where a very strong selection/increased competition effect is not completely compensated by the subsequent positive indirect effect.

An important observation that can be made from statistically significant coefficients of Table 7 is that the increases in entry rates for start-ups that are not knowledge-based have very small (or even negative) overall effects on subsequent employment change, and these effects do not change significantly according to the type of region. While it is true that the type of start-up (knowledge-based versus others) matters more than the type of region, it is also true that the levels of agglomeration and labor productivity in regions matter more for the effects of knowledge-based start-ups than for the effects of other start-ups.

\section{Concluding Remarks}

This study examined differences in the effects of start-up rates on subsequent employment change across regions. In particular, two sources of such differences - 
types of start-ups and types of regions - were analyzed, leading to two main hypotheses. Firstly, increases in the start-up rates of knowledge-based firms will have a greater impact on subsequent employment change than increases in the start-up rates of other firms regardless of the type of region where these start-ups occur; secondly, the impact of increases in start-up rates on subsequent employment change will be greater in regions with higher levels of agglomeration and business dynamics, regardless of the type of start-up.

We find that differences between types of start-ups - namely between knowledge based and other firms - dominate differences in regional agglomeration and economic performance (as measured by labor productivity). Knowledge-based start-ups in high business dynamics regions have essentially two effects on subsequent employment change:

i. First, a displacement (selection) effect (which occurs right from entry), likely brought about by increased competition and efficiency gains, leading to the exit of firms and a negative impact on employment;

ii. Second, an indirect, positive spillover effect, likely brought about by amplified innovation, increased efficiency and greater product variety, leading to increases in employment.

Start-ups in knowledge-based sectors have greater effects on subsequent employment growth than other start-ups, regardless of the type of region where these start-ups occur. This result suggests that knowledge-based start-ups have a greater potential to induce change in markets, bringing about both negative selection effects and positive spillover effects on overall employment.

Regional business dynamics, as measured by agglomeration levels and by labor productivity also matter, however. Differences in the effects of new start-ups on subsequent employment growth between more agglomerated, higher firm growth regions and less agglomerated, lower firm growth regions are greater for knowledgebased start-ups than for other types of start-ups. A particularly interesting result is obtained when modestly agglomerated regions are examined according to their levels of economic performance, as measured by labor productivity, the overall positive effect of knowledge-based entry is positive in high labor productivity regions, but negative in 
low labor productivity regions, where a very strong selection and increased efficiency effect offsets the subsequent positive indirect effect.

The results suggest that, while knowledge-based start-ups (which almost certainly include those more likely to be innovative and have a greater potential for high growth) are likely to impart greater overall benefits on employment than other types of start-ups (likely including the less innovative, low growth ones), these benefits are significantly larger when those start-ups locate in stronger, more dynamic (high agglomeration, high labor productivity) regions. The effects of other types of (non-innovative) start-ups on subsequent employment growth do not change significantly with the type of region where they locate.

Further research should concentrate on other sources of differences between startups, in order to better ascertain which types of start-ups have a greater impact on subsequent employment growth. For instance, the literature finds that larger, better financed entrants are more likely to survive and grow (Geroski, 1995). It is therefore possible that these types of start-ups will have a greater impact on subsequent employment growth than smaller ones. Other sources of differences that may be examined are associated with the innovative potential of start-ups, and include human capital (of both founders and employees) and direct foreign investment (usually associated with technology spillovers.

\section{Acknowledgements}

The authors would like to thank Marcus Dejardin, Michael Fritsch, Pamela Mueller, Andre van Stel, and participants in the Special Session "Entrepreneurship and the Region" of 2007 ERSA Conference at ESSEC Business School (Paris). We are indebted to the Portuguese Ministry of Labor and Social Solidarity and to the Portuguese National Statistics Office (INE) for allowing us access to the data used in this paper. Miguel Torres Preto gratefully acknowledges the financial support of the Portuguese Foundation for Science and Technology (FCT grant SFRH/BD/22648/2005). 


\section{References}

Acs, Z. J., \& Mueller, P. (2008). Employment effects of business dynamics: Mice, Gazelles and Elephants. Small Business Economics, 30, 85-100.

Acs, Z. J., Audretsch, D. B., Braunerhjelm, P., \& Carlsson, B. (2004). The missing link: The knowledge filter and entrepreneurship in endogenous growth. CEPR Discussion Papers 4783, Centre for Economic and Policy Research , London, 2004.

Aghion, P., Blundell, R., Griffith, R., Howitt, P., \& Präntl, S. (2004). Entry and productivity growth: Evidence from microlevel panel data. Journal of the European Economic Association, 2, 265-276.

Anselin, L. (1988). Spatial econometrics: Methods and models. Dordrecht: Kluwer.

Anselin, L., \& Florax, R. (1995). New directions in spatial econometrics: Introduction. In L. Anselin \& R. Florax (Eds.), New directions in spatial econometrics (pp. 3-18). Berlin: Springer.

Arauzo-Carod, J.-M., Liviano-Solis. D., \& Martin-Bofarull, M. (2008). New business formation and employment growth: Some evidence for the Spanish manufacturing industry. Small Business Economics, 30, 73-84.

Ashcroft, B., Love, J., \& Malloy, E. (1991). New firm formation in the British counties with special reference to Scotland. Regional Studies, 25, 395-409.

Audretsch, D. B. (2003). Innovation and spatial externalities. International Regional Science Review, 26, 167-174.

Audretsch, D. B., \& Fritsch, M. (1994). On the measurement of entry rates. Empirica, $21,105-113$.

Audretsch, D. B., \& Thurik, A. R. (2004). The model of the entrepreneurial economy. International Journal of Entrepreneurship Education, 2, 143-166.

Baptista, R. (1998). Industrial clusters and the geography of innovation and production: A survey of the literature. In P. Swann, M. Prevezer and D. Stout (Eds.), The dynamics of industrial clustering (pp. 106-123). London: Oxford University Press.

Baptista, R. (2000). Do innovations diffuse faster within geographical clusters? International Journal of Industrial Organization, 18, 515-535.

Baptista, R., \& Mendonça, J. (2009). Proximity to knowledge sources and the location of knowledge based start-ups. Annals of Regional Science, doi: 10.1007/s00168-0090289-4.

Baptista, R., \& Preto, M. T. (2009). Long term effects of new firm formation by type of start-up. Paper presented at the IECER 2009 - Interdisciplinary European Conference on Entrepreneurship Research, March 2009, Lisbon, Portugal. 
Baptista, R., Escária, V., \& Madruga, P. (2008). Entrepreneurship, regional development and job creation: The case of Portugal. Small Business Economics, 30, 49-58.

Beck, N., \& Katz, J. N. (1995). What to do (and not to do) with time-series crosssection data. American Political Science Review, 89, 634-647.

Beesley, M. E., \& Hamilton, M. T. (1984). Small firms' seedbed role and the concept of turbulence. Journal of Industrial Economics, 33, 217-231.

Birch, D. L. (1981). Who creates jobs? The Public Interest, 65, 3-14.

Blien, U., Südekum, J., \& Wolf, K. (2006). Local employment growth in West Germany: a dynamic panel approach. Labour Economics, 13, 445-458.

Disney, R., Haskel, J., \& Heden, Y. (2003). Entry, exit and establishment survival in UK manufacturing. Journal of Industrial Economics, 51, 91-112.

Feldman, M. P. (1994). The geography of innovation. Dordrecht: Kluwer.

Fritsch, M., \& Noseleit, F. (2009). Investigating the anatomy of the employment effects of new business formation. Jena Economic Research Papers in Economics 2009-001, Friedrich-Schiller-University Jena, Max-Planck-Institute of Economics, Thueringer Universitaets und Landesbibliothek.

Fritsch, M., \& Falck, O. (2007). New business formation by industry over space and time: A multi-dimensional analysis. Regional Studies, 41, 157-172.

Fritsch, M., \& Mueller, P. (2004). The effects of new business formation on regional development over time. Regional Studies, 38, 961-975.

Fritsch, M., \& Mueller, P. (2008). The effect of new business formation on regional development over time: The case of Germany. Small Business Economics, 30, 15-29.

Fritsch, M., Brixy, U., \& Falck, O. (2006). The effect of industry, region and time on new business survival - A multi-dimensional analysis. Review of Industrial Organization, 28, 285-306.

Garofoli, G. (1994). New firm formation and regional development: The case of Italy. Regional Studies, 28, 381-393.

Geroski, P. A. (1995). What do we know about entry? International Journal of Industrial Organization, 13, 421-440.

Glaeser E. L., Kallal, H. D., Scheinkman, J. A. \& Shleifer, A. (1992). Growth in cities. Journal of Political Economy, 100, 1126-1152.

Henrekson, M., \& Johansson, D. (2008). Gazelles as job creators - A survey and interpretation of the evidence. IFN Working Paper Series 733, Research Institute of Industrial Economics, Stockholm, 2008. 
Hoetker, G., \& Agarwal, R. (2007). Death hurts, but it isn't fatal: The post-exit diffusion of knowledge created by innovative companies. Academy of Management Journal, 50, 446-467.

Jaffe, A., Trajtenberg, M., \& Henderson, R. (1993). Geographic localization of knowledge spillovers as evidenced by patent citations. Quarterly Journal of Economics, 108, 577-598.

Mueller, P., van Stel, A. J., \& Storey, D. J. (2008). The effects of new firm formation on regional development over time: The case of Great Britain. Small Business Economics, 30, 59-71.

OECD (2002). OECD science, technology and industrial outlook. Paris: OECD.

Parks, R. W. (1967). Efficient estimation of a system of regression equation when disturbances are both serially and contemporaneously correlated. Journal of the American Statistical Association, 62, 500-509.

Romer, P. M. (1986). Increasing returns and long-run growth. Journal of Political Economy, 94, 1002-1037.

Romer, P. M. (1990). Endogenous technological change. Journal of Political Economy, 98, S71-S102.

Shane, S. (1996). Explaining variation in rates of entrepreneurship in the United States: 1899-1988. Journal of Management, 22, 747-781.

Trivedi, P. K. (1978). Estimation of a distributed lag model under quadratic loss. Econometrica, 46, 1181-1183.

van Praag, M., \& Versloot, P. (2007). What is the value of entrepreneurship? A review of recent research. Small Business Economics, 29, 351-382.

van Stel, A. J., \& Storey, D. J. (2004). The link between firm births and job creation: Is there an Upas tree effect?" Regional Studies, 38, 893-909.

van Stel, A. J., \& Suddle, K. (2008). The impact of new firm formation on regional development in the Netherlands. Small Business Economics, 30, 31-47. 
Table 1: Impact of lagged start-up rates on regional employment growth by agglomeration/business dynamics levels - feasible generalized least

\begin{tabular}{|c|c|c|c|c|c|c|c|c|c|}
\hline \multicolumn{10}{|c|}{ squares } \\
\hline \multirow[b]{2}{*}{ Highly agglomerated regions } & \multirow[t]{2}{*}{ Unrestricted } & \multicolumn{3}{|c|}{$\begin{array}{l}\text { Almon method } \\
\left(4^{\text {th }} \text { order polynomial }\right)\end{array}$} & & \multirow[t]{2}{*}{ Unrestricted } & \multicolumn{3}{|c|}{$\begin{array}{l}\text { Almon method } \\
\left(4^{\text {th }} \text { order polynomial) }\right.\end{array}$} \\
\hline & & & & & Other regions & & & & \\
\hline Start-up rate $\mathrm{t}$ & $\begin{array}{l}-0.902 * * \\
{[-1.97]}\end{array}$ & $\alpha_{0}$ & $\begin{array}{l}-0.488 \\
{[-0.97]}\end{array}$ & -0.488 & Start-up rate $t$ & $\begin{array}{l}0.513 * * * \\
{[3.43]}\end{array}$ & $\alpha_{0}$ & $\begin{array}{l}0.638 * * * \\
{[4.31]}\end{array}$ & 0.638 \\
\hline Start-up rate $\mathrm{t}-1$ & $\begin{array}{l}0.150 \\
{[0.30]}\end{array}$ & $\alpha_{1}$ & $\begin{array}{l}-0.825 \\
{[-1.39]}\end{array}$ & -0.776 & Start-up rate t-1 & $\begin{array}{l}0.674 * * * \\
{[4.04]}\end{array}$ & $\alpha_{1}$ & $\begin{array}{l}-0.811^{* * *} \\
{[-3.47]}\end{array}$ & 0.132 \\
\hline Start-up rate $\mathrm{t}-2$ & $\begin{array}{l}-0.322 \\
{[-0.98]}\end{array}$ & $\alpha_{2}$ & $\begin{array}{l}0.644 * * \\
{[2.39]}\end{array}$ & -0.367 & Start-up rate $\mathrm{t}-2$ & $\begin{array}{l}-0.231 * \\
{[-1.78]}\end{array}$ & $\alpha_{2}$ & $\begin{array}{l}0.356 * * * \\
{[3.25]}\end{array}$ & 0.051 \\
\hline Start-up rate $\mathrm{t}-3$ & $\begin{array}{l}0.347 \\
{[1.31]}\end{array}$ & $\alpha_{3}$ & $\begin{array}{l}-0.112 * * * \\
{[-2.73]}\end{array}$ & 0.265 & Start-up rate $\mathrm{t}-3$ & $\begin{array}{l}0.103 \\
{[0.81]}\end{array}$ & $\alpha_{3}$ & $\begin{array}{l}-0.054 * * * \\
{[-3.12]}\end{array}$ & 0.163 \\
\hline Start-up rate $\mathrm{t}-4$ & $\begin{array}{l}0.827 * * * \\
{[3.34]}\end{array}$ & $\alpha_{4}$ & $\begin{array}{l}0.006 * * * \\
{[2.79]}\end{array}$ & 0.784 & Start-up rate $\mathrm{t}-4$ & $\begin{array}{l}0.451 * * * \\
{[3.47]}\end{array}$ & $\alpha_{4}$ & $\begin{array}{l}0.002 * * * \\
{[2.92]}\end{array}$ & 0.295 \\
\hline Start-up rate $\mathrm{t}-5$ & $\begin{array}{l}1.147 * * * \\
{[4.38]}\end{array}$ & & & 0.982 & Start-up rate $\mathrm{t}-5$ & $\begin{array}{l}0.709 * * * \\
{[5.33]}\end{array}$ & & & 0.334 \\
\hline Start-up rate $\mathrm{t}-6$ & $\begin{array}{l}1.133 * * * \\
{[3.67]}\end{array}$ & & & 0.786 & Start-up rate $\mathrm{t}-6$ & $\begin{array}{l}0.156 \\
{[1.05]}\end{array}$ & & & 0.228 \\
\hline Start-up rate $\mathrm{t}-7$ & $\begin{array}{l}-0.004 \\
{[-0.01]}\end{array}$ & & & 0.257 & Start-up rate t-7 & $\begin{array}{l}-0.607 * * * \\
{[-3.94]}\end{array}$ & & & -0.018 \\
\hline Start-up rate $\mathrm{t}-8$ & $\begin{array}{l}-0.859 * * * \\
{[-3.15]}\end{array}$ & & & -0.415 & Start-up rate $\mathrm{t}-8$ & $\begin{array}{l}-0.378 * * \\
{[-2.52]}\end{array}$ & & & -0.336 \\
\hline Start-up rate t-9 & $\begin{array}{l}-0.788 * * * \\
{[-2.87]}\end{array}$ & & & -0.904 & Start-up rate t-9 & $\begin{array}{l}-0.183 \\
{[-1.20]}\end{array}$ & & & -0.602 \\
\hline Start-up rate $\mathrm{t}-10$ & $\begin{array}{l}-0.909 * * * \\
{[-3.15]}\end{array}$ & & & -0.752 & Start-up rate $\mathrm{t}-10$ & $\begin{array}{l}-0.772 * * * \\
{[-4.98]}\end{array}$ & & & -0.628 \\
\hline$\sum$ coefficients start-up rate $\mathrm{t}$ to $\mathrm{t}-10$ & -0.180 & & & $-0.629 / 1.442^{+}$ & $\sum$ coefficients start-up rate $\mathrm{t}$ to $\mathrm{t}-10$ & 0.435 & & & $0.256 / 1.840^{+}$ \\
\hline & & & & & $\begin{array}{l}\text { Firm size } \\
\text { Population density } \\
\text { Constant } \\
\text { Wald } \\
\text { No. of observations }\end{array}$ & $\begin{array}{l}0.047 \\
{[0.30]} \\
-0.001 \\
{[-0.25]} \\
1.132 \\
{[0.50]} \\
193.48 \\
510\end{array}$ & & & $\begin{array}{l}0.019 \\
{[0.12]} \\
0.001 \\
{[0.19]} \\
2.247 \\
{[0.99]} \\
95.30 \\
510\end{array}$ \\
\hline
\end{tabular}


Table 2: Impact of lagged knowledge-based start-up rates on regional employment growth by agglomeration/business dynamics levels - feasible

\begin{tabular}{|c|c|c|c|c|c|c|c|c|c|}
\hline & Unrestricted & \multicolumn{4}{|c|}{$\begin{array}{l}\text { Almon method } \\
\left(4^{\text {th }} \text { order polynomial }\right)\end{array}$} & Unrestricted & \multicolumn{3}{|c|}{$\begin{array}{l}\text { Almon method } \\
\left(4^{\text {th }} \text { order polynomial }\right)\end{array}$} \\
\hline \multicolumn{10}{|l|}{ Knowledge-based firms } \\
\hline \multirow{2}{*}{$\begin{array}{l}\text { Highly agglomerated regions } \\
\text { Start-up rate } \mathrm{t}\end{array}$} & & & & & Other regions & & & & \\
\hline & $\begin{array}{l}-10.915 * * * \\
{[-4.00]}\end{array}$ & $\alpha_{0}$ & $\begin{array}{l}-7.355 * * \\
{[-2.46]}\end{array}$ & -7.355 & Start-up rate $t$ & $\begin{array}{l}2.553 \\
{[1.25]}\end{array}$ & $\alpha_{0}$ & $\begin{array}{l}3.114 \\
{[1.58]}\end{array}$ & 3.114 \\
\hline Start-up rate t-1 & $\begin{array}{l}-11.568 * * * \\
{[-3.64]}\end{array}$ & $\alpha_{1}$ & $\begin{array}{l}-14.638 * * * \\
{[-3.11]}\end{array}$ & -14.229 & Start-up rate $\mathrm{t}-1$ & $\begin{array}{l}-1.198 \\
{[-0.52]}\end{array}$ & $\alpha_{1}$ & $\begin{array}{l}-11.533 * * * \\
{[-3.41]}\end{array}$ & -3.464 \\
\hline Start-up rate $\mathrm{t}-2$ & $\begin{array}{l}-11.925 * * * \\
{[-4.82]}\end{array}$ & $\alpha_{2}$ & $\begin{array}{l}9.071 * * * \\
{[3.95]}\end{array}$ & -10.324 & Start-up rate $\mathrm{t}-2$ & $\begin{array}{l}-6.378 * * * \\
{[-2.81]}\end{array}$ & $\alpha_{2}$ & $\begin{array}{l}5.768^{* * * *} \\
{[3.31]}\end{array}$ & -3.086 \\
\hline Start-up rate $\mathrm{t}-3$ & $\begin{array}{l}-2.260 \\
{[-0.97]}\end{array}$ & $\alpha_{3}$ & $\begin{array}{l}-1.368 * * * \\
{[-3.77]}\end{array}$ & -1.673 & Start-up rate $\mathrm{t}-3$ & $\begin{array}{l}0.668 \\
{[0.28]}\end{array}$ & $\alpha_{3}$ & $\begin{array}{l}-0.851 * * * \\
{[-2.94]}\end{array}$ & 0.496 \\
\hline Start-up rate $\mathrm{t}-4$ & $\begin{array}{l}7.670^{* * * *} \\
{[3.25]}\end{array}$ & $\alpha_{4}$ & $\begin{array}{l}0.060 * * * \\
{[3.36]}\end{array}$ & 7.141 & Start-up rate $\mathrm{t}-4$ & $\begin{array}{l}7.275^{* * *} \\
{[2.81]}\end{array}$ & $\alpha_{4}$ & $\begin{array}{l}0.038^{* *} \\
{[2.52]}\end{array}$ & 4.427 \\
\hline Start-up rate t-5 & $\begin{array}{l}12.666^{* * * *} \\
{[5.16]}\end{array}$ & & & 12.982 & Start-up rate t-5 & $\begin{array}{l}9.334 * * * \\
{[3.46]}\end{array}$ & & & 6.756 \\
\hline Start-up rate $\mathrm{t}-6$ & $\begin{array}{l}20.154 * * * \\
{[6.35]}\end{array}$ & & & 14.166 & Start-up rate $\mathrm{t}-6$ & $\begin{array}{l}5.972^{*} \\
{[1.95]}\end{array}$ & & & 6.429 \\
\hline Start-up rate t-7 & $\begin{array}{l}11.103 * * * \\
{[3.44]}\end{array}$ & & & 10.454 & Start-up rate $\mathrm{t}-7$ & $\begin{array}{l}-3.749 \\
{[-1.12]}\end{array}$ & & & 3.295 \\
\hline Start-up rate $\mathrm{t}-8$ & $\begin{array}{l}-1.992 \\
{[-0.65]}\end{array}$ & & & 3.061 & Start-up rate $\mathrm{t}-8$ & $\begin{array}{l}-1.588 \\
{[-0.45]}\end{array}$ & & & -1.899 \\
\hline Start-up rate t-9 & $\begin{array}{l}-2.784 \\
{[-0.90]}\end{array}$ & & & -5.351 & Start-up rate t-9 & $\begin{array}{l}-1.900 \\
{[-0.51]}\end{array}$ & & & -7.502 \\
\hline Start-up rate $\mathrm{t}-10$ & $\begin{array}{l}-11.281 * * * \\
{[-3.59]}\end{array}$ & & & -10.671 & Start-up rate $\mathrm{t}-10$ & $\begin{array}{l}-12.893 * * * \\
{[-4.98]}\end{array}$ & & & -10.967 \\
\hline \multirow[t]{6}{*}{$\sum$ coefficients start-up rate $\mathrm{t}$ to $\mathrm{t}-10$} & -1.132 & & & $-1.799 / 14.224^{+}$ & $\sum$ coefficients start-up rate $\mathrm{t}$ to $\mathrm{t}-10$ & -1.904 & & & $-2.402 / 17.966^{+}$ \\
\hline & & & & & Firm size & $\begin{array}{l}0.097 \\
{[0.71]}\end{array}$ & & & $\begin{array}{l}0.060 \\
{[0.43]}\end{array}$ \\
\hline & & & & & Population density & $\begin{array}{l}0.000 \\
{[0.12]}\end{array}$ & & & $\begin{array}{l}0.000 \\
{[0.13]}\end{array}$ \\
\hline & & & & & Constant & $\begin{array}{l}4.793 * * \\
{[2.55]}\end{array}$ & & & $\begin{array}{l}5.209 * * * \\
{[2.74]}\end{array}$ \\
\hline & & & & & Wald & 133.42 & & & 77.21 \\
\hline & & & & & No. of observations & 510 & & & 510 \\
\hline
\end{tabular}


Table 3: Impact of lagged KB and other firms' start-up rates on regional employment growth by agglomeration/business dynamics levels -

\begin{tabular}{|c|c|c|c|c|c|c|c|c|c|}
\hline \multirow{3}{*}{$\begin{array}{l}\text { Highly agglomerated regions } \\
\text { Knowledge-based firms }\end{array}$} & \multirow[t]{2}{*}{ Unrestricted } & \multicolumn{4}{|c|}{$\begin{array}{l}\text { Almon method } \\
\left(4^{\text {th }} \text { order polynomial) }\right.\end{array}$} & \multirow[t]{2}{*}{ Unrestricted } & \multicolumn{3}{|c|}{$\begin{array}{l}\text { Almon method } \\
\left(4^{\text {th }} \text { order polynomial }\right)\end{array}$} \\
\hline & & & & & & & & & \\
\hline & & & & & Other firms & & & & \\
\hline Start-up rate $\mathrm{t}$ & $\begin{array}{l}0.660 \\
{[0.12]}\end{array}$ & $\alpha_{0}$ & $\begin{array}{l}-6.244 \\
{[-1.07]}\end{array}$ & -6.244 & Start-up rate $t$ & $\begin{array}{l}-1.230 \\
{[-1.57]}\end{array}$ & $\alpha_{0}$ & $\begin{array}{l}0.199 \\
{[0.21]}\end{array}$ & 0.199 \\
\hline Start-up rate $\mathrm{t}-1$ & $\begin{array}{l}-14.962 * * * \\
{[-2.95]}\end{array}$ & $\alpha_{1}$ & $\begin{array}{l}1.630 \\
{[0.13]}\end{array}$ & -5.914 & Start-up rate t-1 & $\begin{array}{l}1.998 * * \\
{[2.56]}\end{array}$ & $\alpha_{1}$ & $\begin{array}{l}-1.464 \\
{[-0.96]}\end{array}$ & -0.460 \\
\hline Start-up rate $\mathrm{t}-2$ & $\begin{array}{l}-1.219 \\
{[-0.29]}\end{array}$ & $\alpha_{2}$ & $\begin{array}{l}-1.885 \\
{[-0.30]}\end{array}$ & -6.220 & Start-up rate $\mathrm{t}-2$ & $\begin{array}{l}-0.198 \\
{[-0.43]}\end{array}$ & $\alpha_{2}$ & $\begin{array}{l}0.980 \\
{[1.43]}\end{array}$ & -0.124 \\
\hline Start-up rate $\mathrm{t}-3$ & $\begin{array}{l}-8.013 \\
{[-1.64]}\end{array}$ & $\alpha_{3}$ & $\begin{array}{l}0.632 \\
{[0.61]}\end{array}$ & -5.065 & Start-up rate $\mathrm{t}-3$ & $\begin{array}{l}0.893^{*} \\
{[1.84]}\end{array}$ & $\alpha_{3}$ & $\begin{array}{l}-0.185^{*} \\
{[-1.73]}\end{array}$ & 0.462 \\
\hline Start-up rate $\mathrm{t}-4$ & $\begin{array}{l}8.725^{* *} \\
{[1.97]}\end{array}$ & $\alpha_{4}$ & $\begin{array}{l}-0.047 \\
{[-0.89]}\end{array}$ & -1.479 & Start-up rate $\mathrm{t}-4$ & $\begin{array}{l}-0.081 \\
{[-0.20]}\end{array}$ & $\alpha_{4}$ & $\begin{array}{l}0.010^{*} \\
{[1.89]}\end{array}$ & 0.801 \\
\hline Start-up rate $\mathrm{t}-5$ & $\begin{array}{l}-5.973 \\
{[-1.42]}\end{array}$ & & & 4.375 & Start-up rate t-5 & $\begin{array}{l}1.566 * * * \\
{[3.78]}\end{array}$ & & & 0.638 \\
\hline Start-up rate $\mathrm{t}-6$ & $\begin{array}{l}-1.496 \\
{[-0.24]}\end{array}$ & & & 11.206 & Start-up rate t-6 & $\begin{array}{l}1.485 * * * \\
{[2.96]}\end{array}$ & & & -0.037 \\
\hline Start-up rate t-7 & $\begin{array}{l}34.097 * * * \\
{[4.05]}\end{array}$ & & & 16.592 & Start-up rate t-7 & $\begin{array}{l}-2.671 * * * \\
{[-3.52]}\end{array}$ & & & -0.991 \\
\hline Start-up rate $\mathrm{t}-8$ & $\begin{array}{l}9.903 \\
{[1.18]}\end{array}$ & & & 16.982 & Start-up rate $\mathrm{t}-8$ & $\begin{array}{l}-1.603 * * \\
{[-2.17]}\end{array}$ & & & -1.746 \\
\hline Start-up rate t-9 & $\begin{array}{l}7.138 \\
{[0.85]}\end{array}$ & & & 7.693 & Start-up rate t-9 & $\begin{array}{l}-1.432 * \\
{[-1.96]}\end{array}$ & & & -1.580 \\
\hline Start-up rate $\mathrm{t}-10$ & $\begin{array}{l}-10.412 \\
{[-1.24]}\end{array}$ & & & -17.086 & Start-up rate $\mathrm{t}-10$ & $\begin{array}{l}-0.306 \\
{[-4.98]}\end{array}$ & & & 0.473 \\
\hline$\sum$ coefficients start-up rate $\mathrm{t}$ to $\mathrm{t}-10$ & 18.448 & & & $14.838 / 31.924^{+}$ & $\sum$ coefficients start-up rate $\mathrm{t}$ to $\mathrm{t}-10$ & -1.579 & & & -2.364 \\
\hline \multicolumn{10}{|l|}{ Other regions } \\
\hline Knowledge-based firms & & & & & Other firms & & & & \\
\hline Start-up rate $\mathrm{t}$ & $\begin{array}{l}-0.278 \\
{[-0.12]}\end{array}$ & $\alpha_{0}$ & $\begin{array}{l}-0.626 \\
{[-0.25]}\end{array}$ & -0.626 & Start-up rate $\mathrm{t}$ & $\begin{array}{l}0.399 * \\
{[1.75]}\end{array}$ & $\alpha_{0}$ & $\begin{array}{l}0.585^{* *} \\
{[2.47]}\end{array}$ & 0.585 \\
\hline Start-up rate t- 1 & $\begin{array}{l}-4.757 * \\
{[-1.80]}\end{array}$ & $\alpha_{1}$ & $\begin{array}{l}-2.242 \\
{[-0.50]}\end{array}$ & -3.031 & Start-up rate t-1 & $\begin{array}{l}1.003 * * * \\
{[3.95]}\end{array}$ & $\alpha_{1}$ & $\begin{array}{l}-0.871 * * \\
{[-2.23]}\end{array}$ & 0.147 \\
\hline Start-up rate $\mathrm{t}-2$ & $\begin{array}{l}-2.948 \\
{[-1.05]}\end{array}$ & $\alpha_{2}$ & $\begin{array}{l}-0.397 \\
{[-0.17]}\end{array}$ & -4.970 & Start-up rate $\mathrm{t}-2$ & $\begin{array}{l}-0.169 \\
{[-0.79]}\end{array}$ & $\alpha_{2}$ & $\begin{array}{l}0.521 * * * \\
{[2.86]}\end{array}$ & 0.269 \\
\hline
\end{tabular}




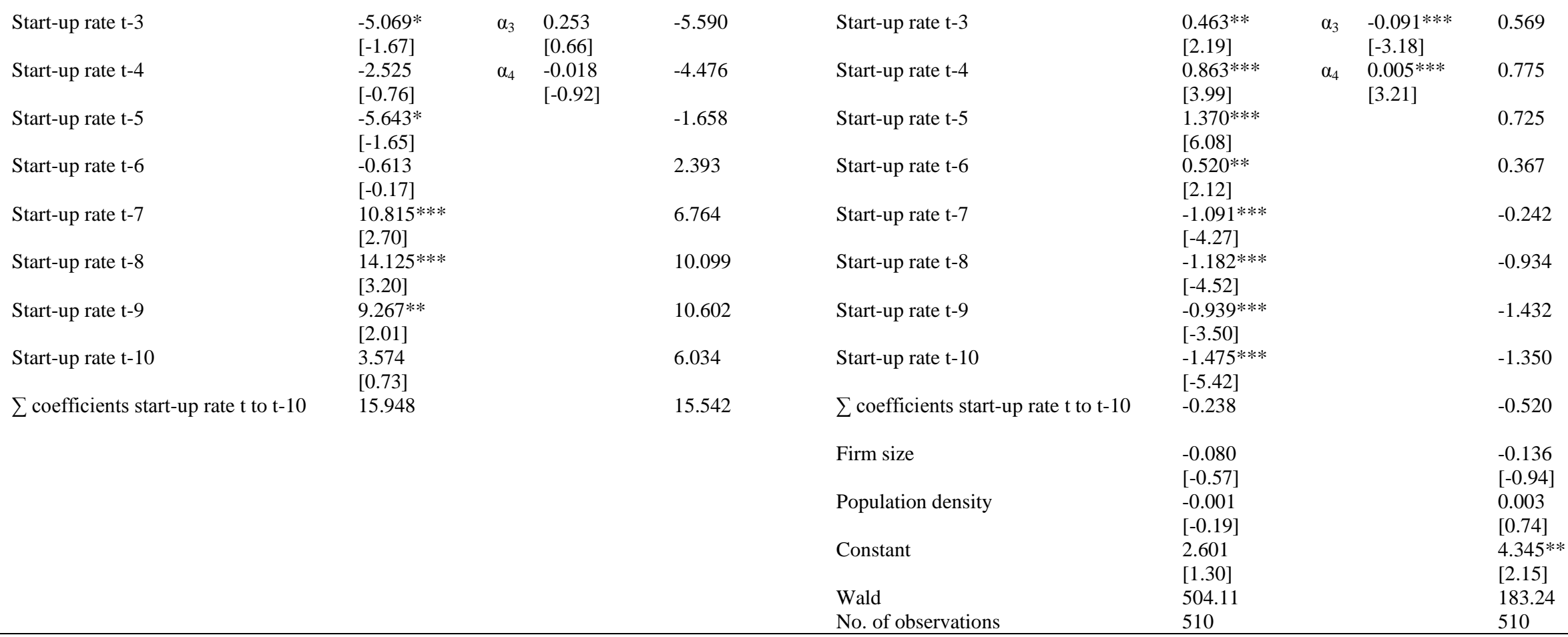


Table 4: Impact of lagged start-up rates on regional employment growth by labor productivity-feasible generalized least squares

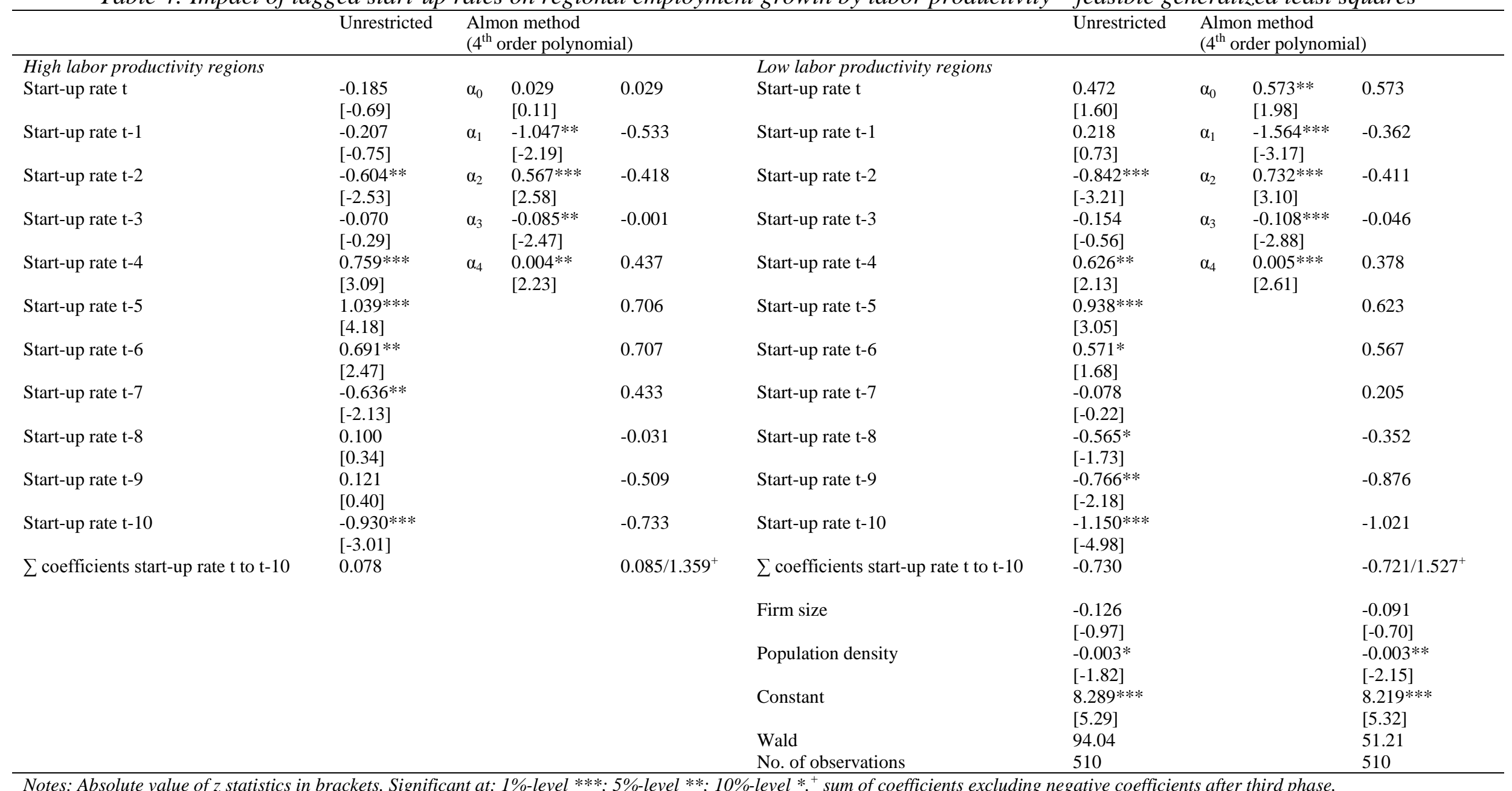


Table 5: Impact of lagged knowledge-based start-up rates on regional employment growth by labor productivity-feasible generalized least

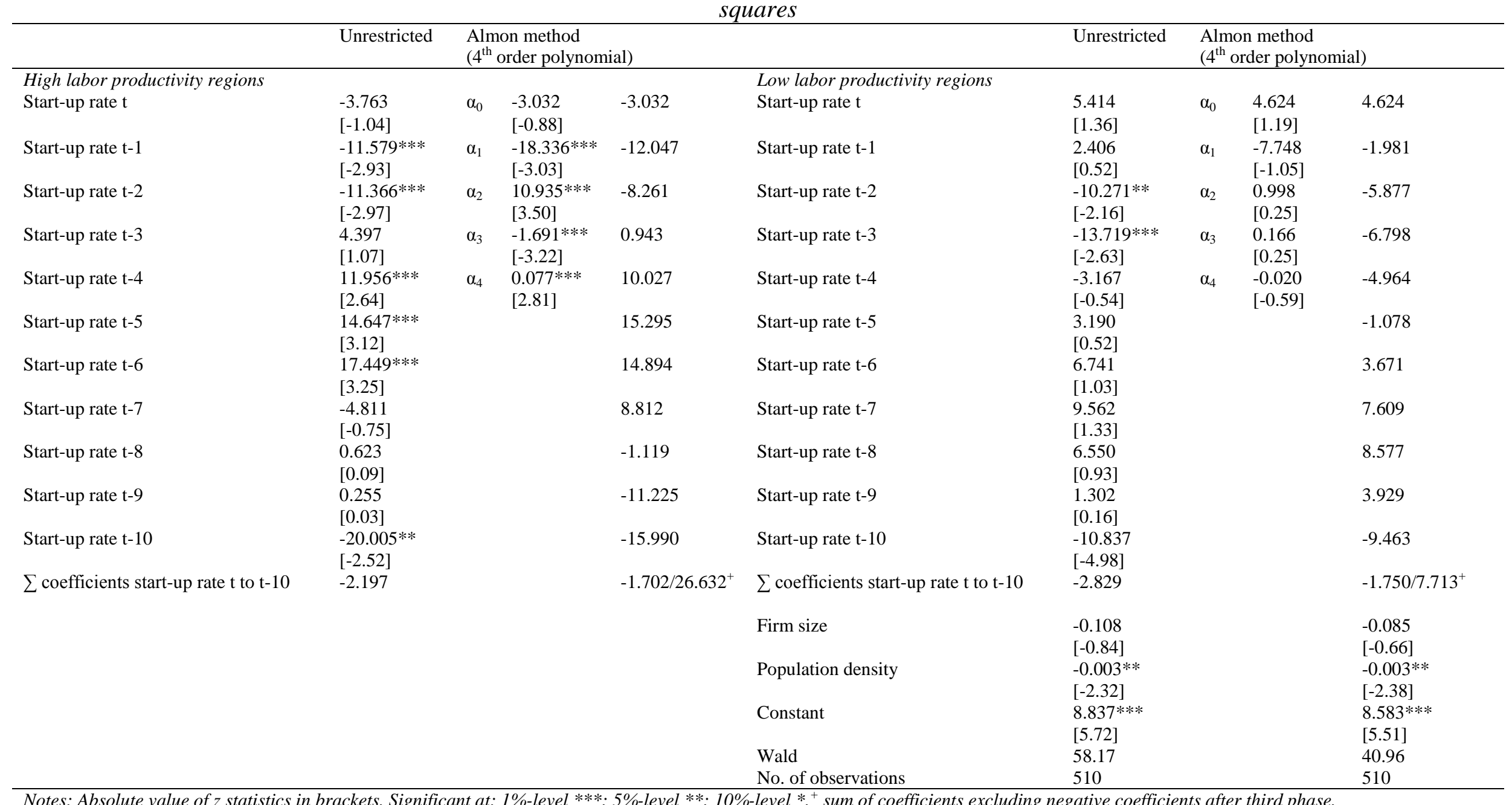


Table 6: Impact of lagged knowledge-based and other firms' start-up rates on regional employment growth by labor productivity - feasible

\begin{tabular}{|c|c|c|c|c|c|c|c|c|c|}
\hline \multirow{2}{*}{ High labor productivity regions } & \multirow[t]{2}{*}{ Unrestricted } & \multicolumn{4}{|c|}{$\begin{array}{l}\text { Almon method } \\
\left(4^{\text {th }} \text { order polynomial }\right)\end{array}$} & \multirow[t]{2}{*}{ Unrestricted } & \multicolumn{3}{|c|}{$\begin{array}{l}\text { Almon method } \\
\left(4^{\text {th }} \text { order polynomial) }\right.\end{array}$} \\
\hline & & & & & & & & & \\
\hline Knowledge-based firms & & & & & Other firms & & & & \\
\hline Start-up rate $\mathrm{t}$ & $\begin{array}{l}-4.771 \\
{[-1.04]}\end{array}$ & $\alpha_{0}$ & $\begin{array}{l}-6.805 \\
{[-1.38]}\end{array}$ & -6.805 & Start-up rate $\mathrm{t}$ & $\begin{array}{l}-0.759 * \\
{[-1.65]}\end{array}$ & $\alpha_{0}$ & $\begin{array}{l}0.072 \\
{[0.15]}\end{array}$ & 0.072 \\
\hline Start-up rate $\mathrm{t}-1$ & $\begin{array}{l}-13.740 * * * \\
{[-2.67]}\end{array}$ & $\alpha_{1}$ & $\begin{array}{l}-10.122 \\
{[-1.17]}\end{array}$ & -9.726 & Start-up rate t-1 & $\begin{array}{l}0.199 \\
{[0.42]}\end{array}$ & $\alpha_{1}$ & $\begin{array}{l}-1.288 \\
{[-1.39]}\end{array}$ & -0.672 \\
\hline Start-up rate $\mathrm{t}-2$ & $\begin{array}{l}0.968 \\
{[0.19]}\end{array}$ & $\alpha_{2}$ & $\begin{array}{l}8.806^{* * *} \\
{[2.04]}\end{array}$ & -3.921 & Start-up rate $\mathrm{t}-2$ & $\begin{array}{l}-1.082 * * \\
{[-2.56]}\end{array}$ & $\alpha_{2}$ & $\begin{array}{l}0.619 \\
{[1.46]}\end{array}$ & -0.602 \\
\hline Start-up rate $\mathrm{t}-3$ & $\begin{array}{l}13.952 * * \\
{[2.50]}\end{array}$ & $\alpha_{3}$ & $\begin{array}{l}-1.700 * * \\
{[-2.34]}\end{array}$ & 3.791 & Start-up rate $\mathrm{t}-3$ & $\begin{array}{l}-0.867 * * \\
{[-1.99]}\end{array}$ & $\alpha_{3}$ & $\begin{array}{l}-0.077 \\
{[-1.16]}\end{array}$ & -0.087 \\
\hline Start-up rate $\mathrm{t}-4$ & $\begin{array}{l}10.345^{*} \\
{[1.69]}\end{array}$ & $\alpha_{4}$ & $\begin{array}{l}0.094 * * \\
{[2.44]}\end{array}$ & 8.841 & Start-up rate $\mathrm{t}-4$ & $\begin{array}{l}0.861^{*} \\
{[1.89]}\end{array}$ & $\alpha_{4}$ & $\begin{array}{l}0.003 \\
{[0.77]}\end{array}$ & 0.565 \\
\hline Start-up rate t-5 & $\begin{array}{l}-4.659 \\
{[-0.78]}\end{array}$ & & & 8.910 & Start-up rate t-5 & $\begin{array}{l}2.501 * * * \\
{[5.45]}\end{array}$ & & & 1.108 \\
\hline Start-up rate $\mathrm{t}-6$ & $\begin{array}{l}5.876 \\
{[0.94]}\end{array}$ & & & 3.935 & Start-up rate $\mathrm{t}-6$ & $\begin{array}{l}1.863 * * * \\
{[3.69]}\end{array}$ & & & 1.356 \\
\hline Start-up rate t- 7 & $\begin{array}{l}-1.458 \\
{[-0.19]}\end{array}$ & & & -3.900 & Start-up rate $\mathrm{t}-7$ & $\begin{array}{l}-0.289 \\
{[-0.54]}\end{array}$ & & & 1.184 \\
\hline Start-up rate $\mathrm{t}-8$ & $\begin{array}{l}-3.706 \\
{[-0.39]}\end{array}$ & & & -10.155 & Start-up rate $\mathrm{t}-8$ & $\begin{array}{l}0.086 \\
{[0.15]}\end{array}$ & & & 0.527 \\
\hline Start-up rate t-9 & $\begin{array}{l}-8.358 \\
{[-0.79]}\end{array}$ & & & -8.141 & Start-up rate t-9 & $\begin{array}{l}-0.248 \\
{[-0.40]}\end{array}$ & & & -0.618 \\
\hline Start-up rate t-10 & $\begin{array}{l}5.845 \\
{[0.50]}\end{array}$ & & & 11.085 & Start-up rate $\mathrm{t}-10$ & $\begin{array}{l}-2.387 * * * \\
{[-4.98]}\end{array}$ & & & -2.194 \\
\hline$\sum$ coefficients start-up rate $\mathrm{t}$ to $\mathrm{t}-10$ & 0.294 & & & $-6.085 / 5.026^{+}$ & $\sum$ coefficients start-up rate $\mathrm{t}$ to $\mathrm{t}-10$ & -0.122 & & & 0.639 \\
\hline \multicolumn{10}{|l|}{ Low labor productivity regions } \\
\hline Knowledge-based firms & & & & & Other firms & & & & \\
\hline Start-up rate $\mathrm{t}$ & $\begin{array}{l}-1.016 \\
{[-0.22]}\end{array}$ & $\alpha_{0}$ & $\begin{array}{l}-3.278 \\
{[-0.71]}\end{array}$ & -3.278 & Start-up rate $\mathrm{t}$ & $\begin{array}{l}0.372 \\
{[1.03]}\end{array}$ & $\alpha_{0}$ & $\begin{array}{l}0.715^{*} \\
{[1.93]}\end{array}$ & 0.715 \\
\hline Start-up rate $\mathrm{t}-1$ & $\begin{array}{l}-4.245 \\
{[-0.79]}\end{array}$ & $\alpha_{1}$ & $\begin{array}{l}5.083 \\
{[0.60]}\end{array}$ & -3.462 & Start-up rate $\mathrm{t}-1$ & $\begin{array}{l}0.489 \\
{[1.34]}\end{array}$ & $\alpha_{1}$ & $\begin{array}{l}-1.690 * * * \\
{[-2.65]}\end{array}$ & -0.169 \\
\hline Start-up rate $\mathrm{t}-2$ & $\begin{array}{l}-7.418 \\
{[-1.28]}\end{array}$ & $\alpha_{2}$ & $\begin{array}{l}-6.698 \\
{[-1.46]}\end{array}$ & -9.173 & Start-up rate $\mathrm{t}-2$ & $\begin{array}{l}-0.537 \\
{[-1.56]}\end{array}$ & $\alpha_{2}$ & $\begin{array}{l}0.958 * * * \\
{[3.13]}\end{array}$ & 0.012 \\
\hline
\end{tabular}




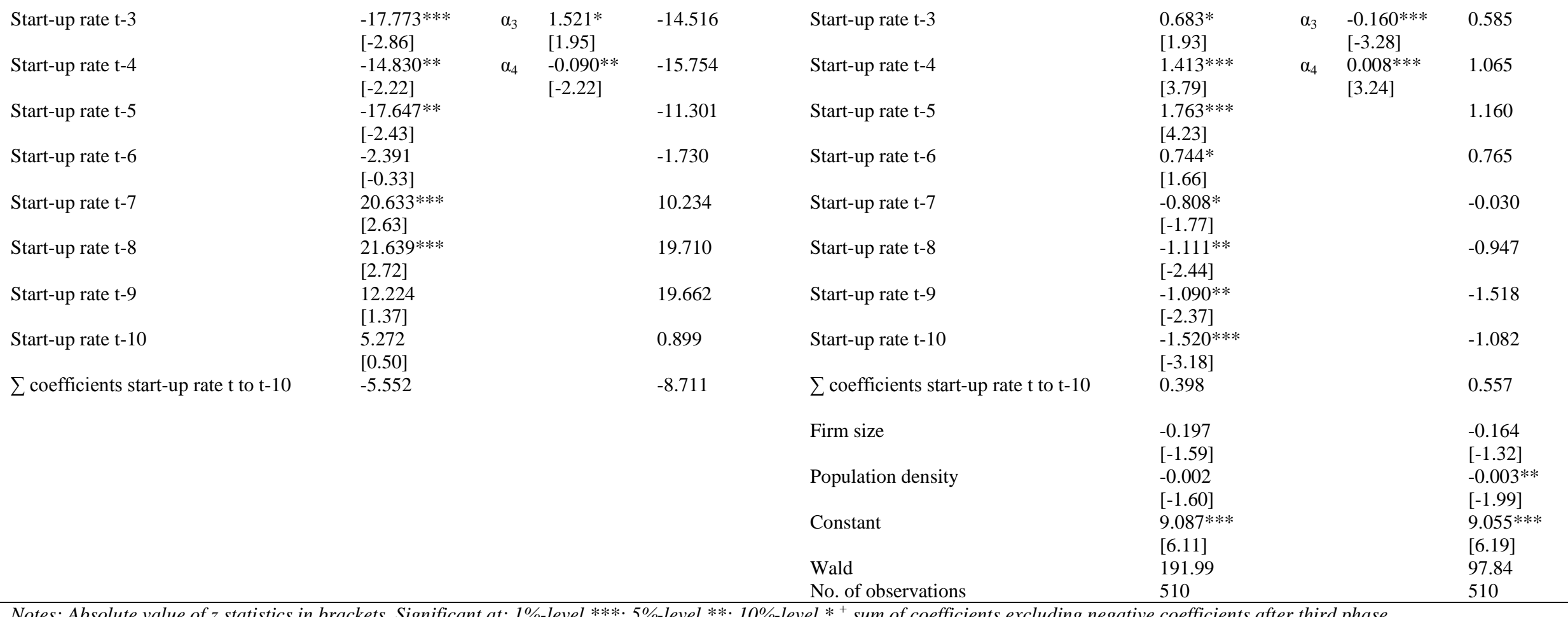


Figure 1: Estimated lag structure ( $4^{\text {th }}$ order Almon polynomial) of the impact of the formation of all start-ups on regional employment change by agglomeration/business dynamics levels - feasible generalized least squares

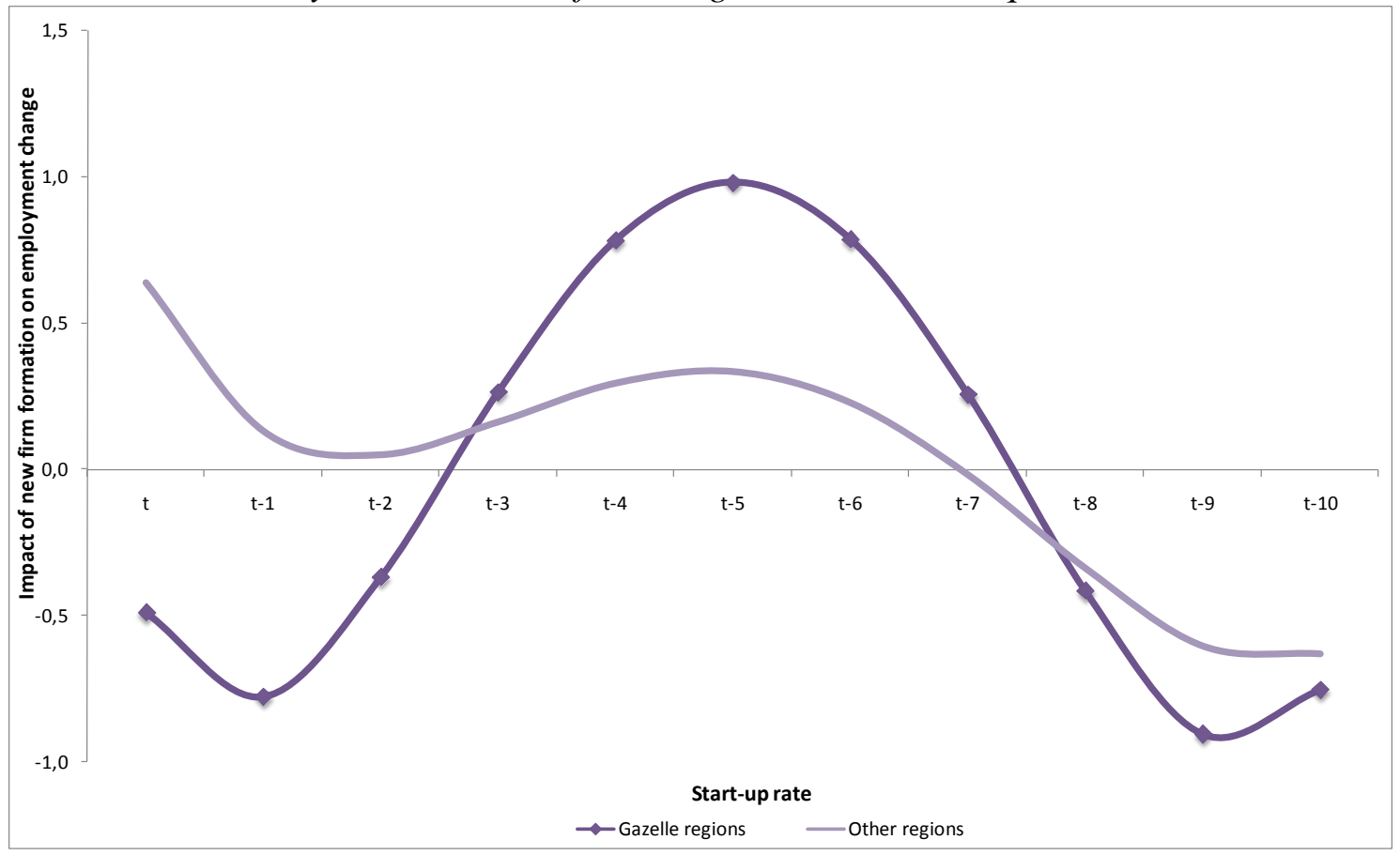

Figure 2: Estimated lag structure ( $4^{\text {th }}$ order Almon polynomial) of the impact of the formation of knowledge-based firms on regional employment change by agglomeration/business dynamics levels - feasible generalized least squares

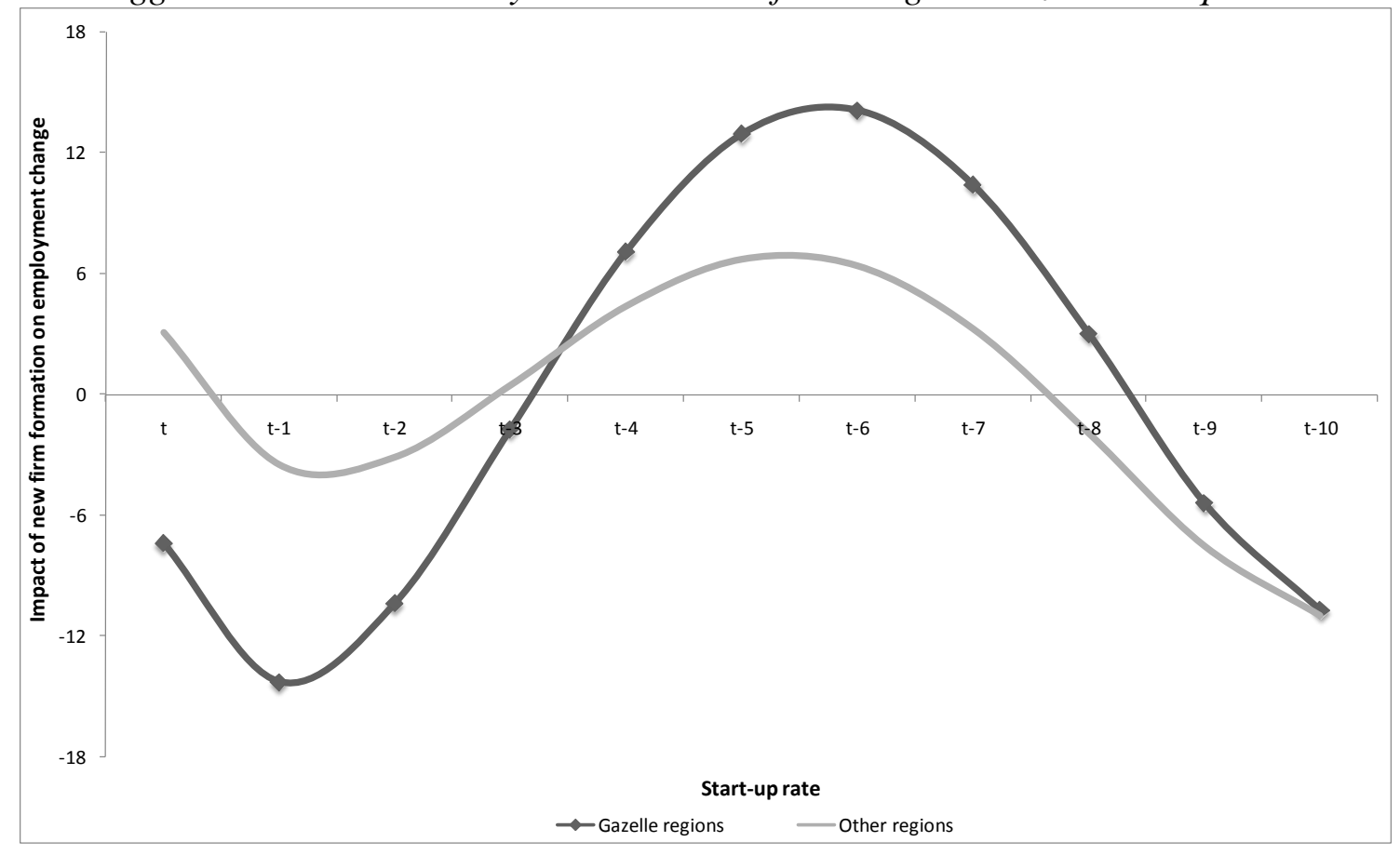


Figure 3: Estimated lag structure ( $4^{\text {th }}$ order Almon polynomial) of the impact of the formation of knowledge-based and other firms on regional employment change by agglomeration/business dynamics levels - feasible generalized least squares

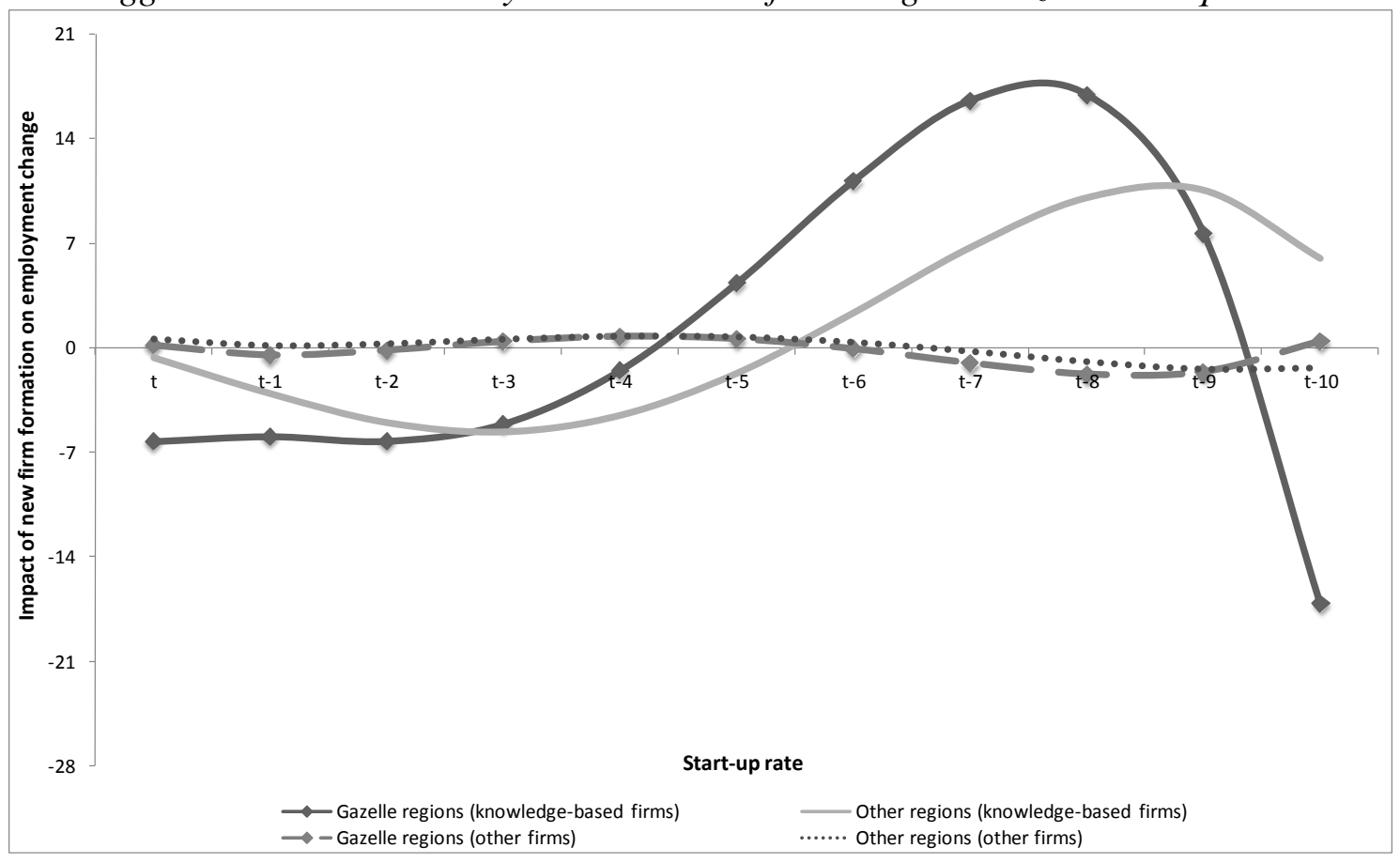

Figure 4: Estimated lag structure (4 ${ }^{\text {th }}$ order Almon polynomial) of the impact of the formation of all start-ups on regional employment change by labor productivityfeasible generalized least squares

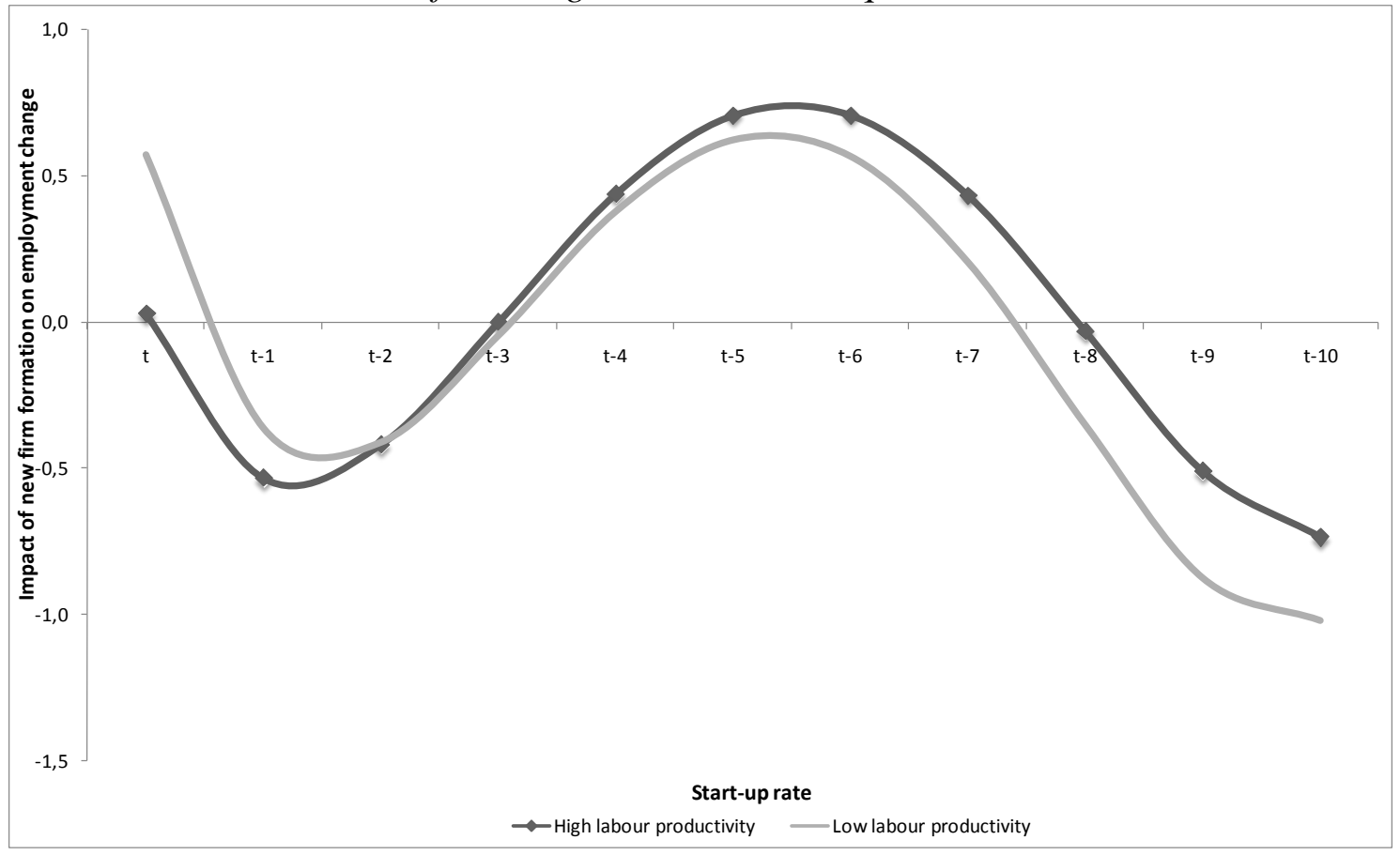


Figure 5: Estimated lag structure ( $4^{\text {th }}$ order Almon polynomial) of the impact of the formation of knowledge-based firms on regional employment change by labor productivity - feasible generalized least squares

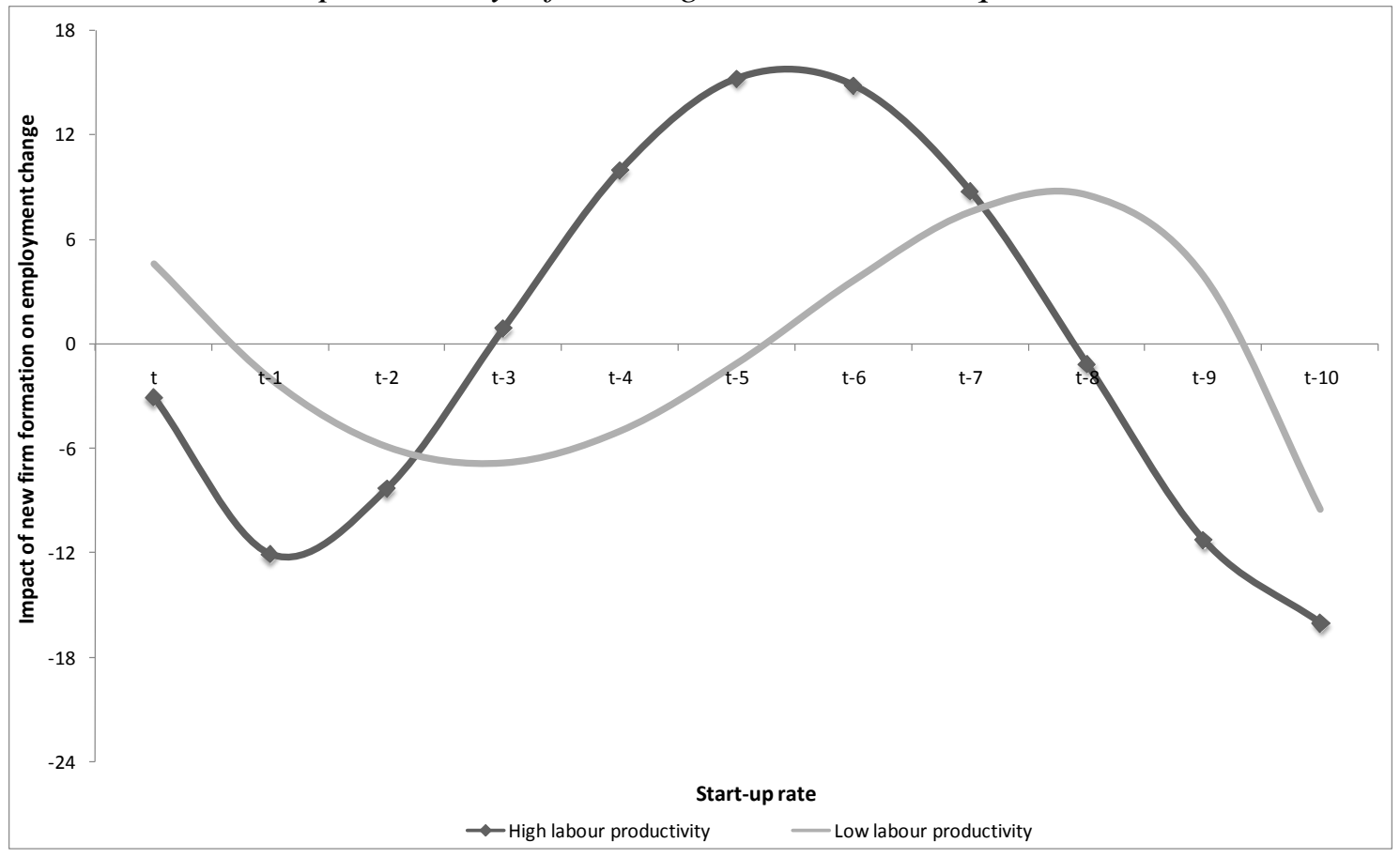

Figure 6: Estimated lag structure ( $4^{\text {th }}$ order Almon polynomial) of the impact of the formation of knowledge-based and other firms on regional employment change by labor productivity - feasible generalized least squares

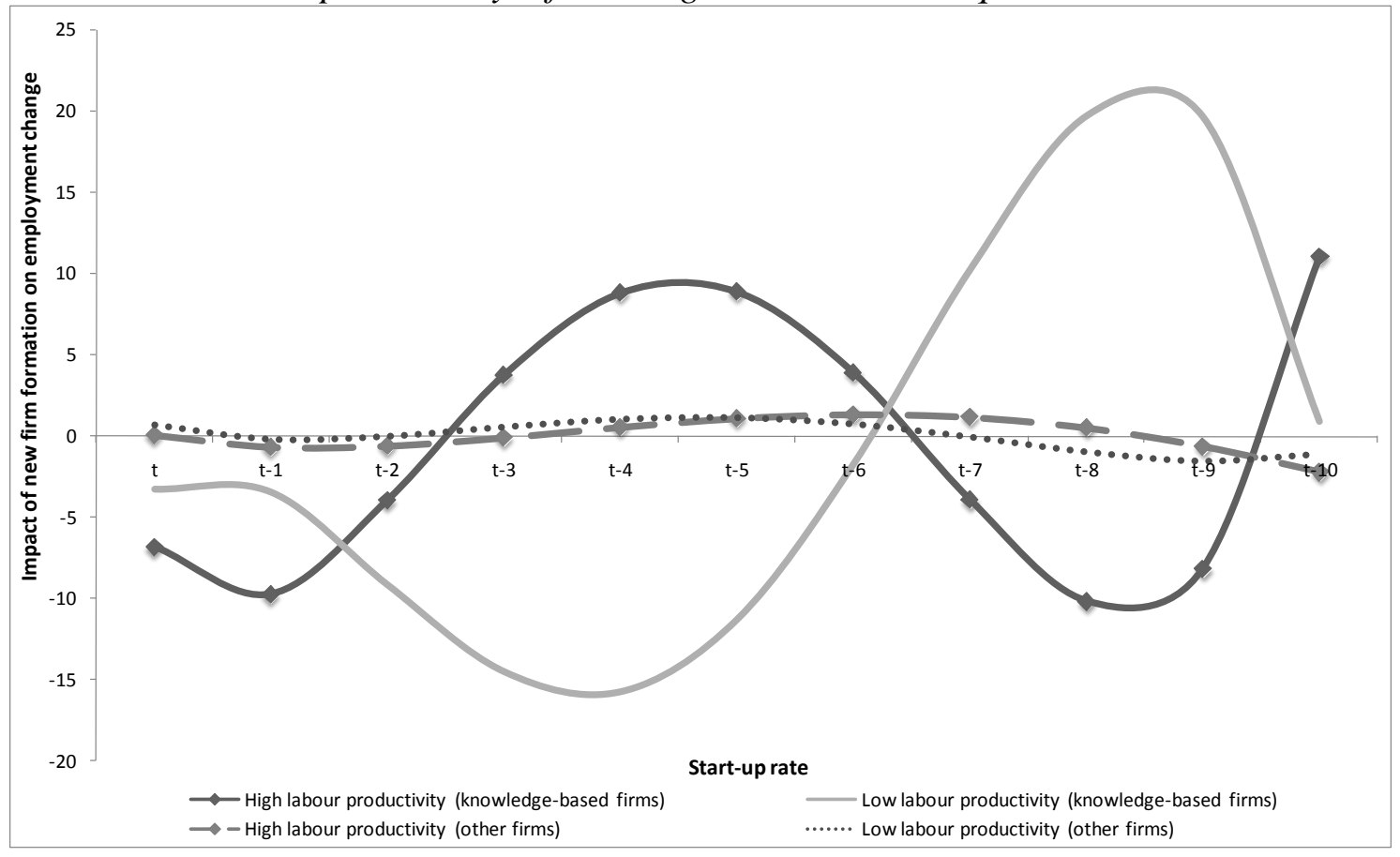


Table 7: Overall effect of new business formation on regional employment change over time

Sum of coefficients (in parentheses: without negative coefficients after phase III)

Feasible generalized least squares Robust fixed effects

Unrest- Almon method Unrest- Almon method

ricted

$\left(4^{\text {th }}\right.$ order

ricted

$\left(4^{\text {th }}\right.$ order

polynomial)

polynomial)

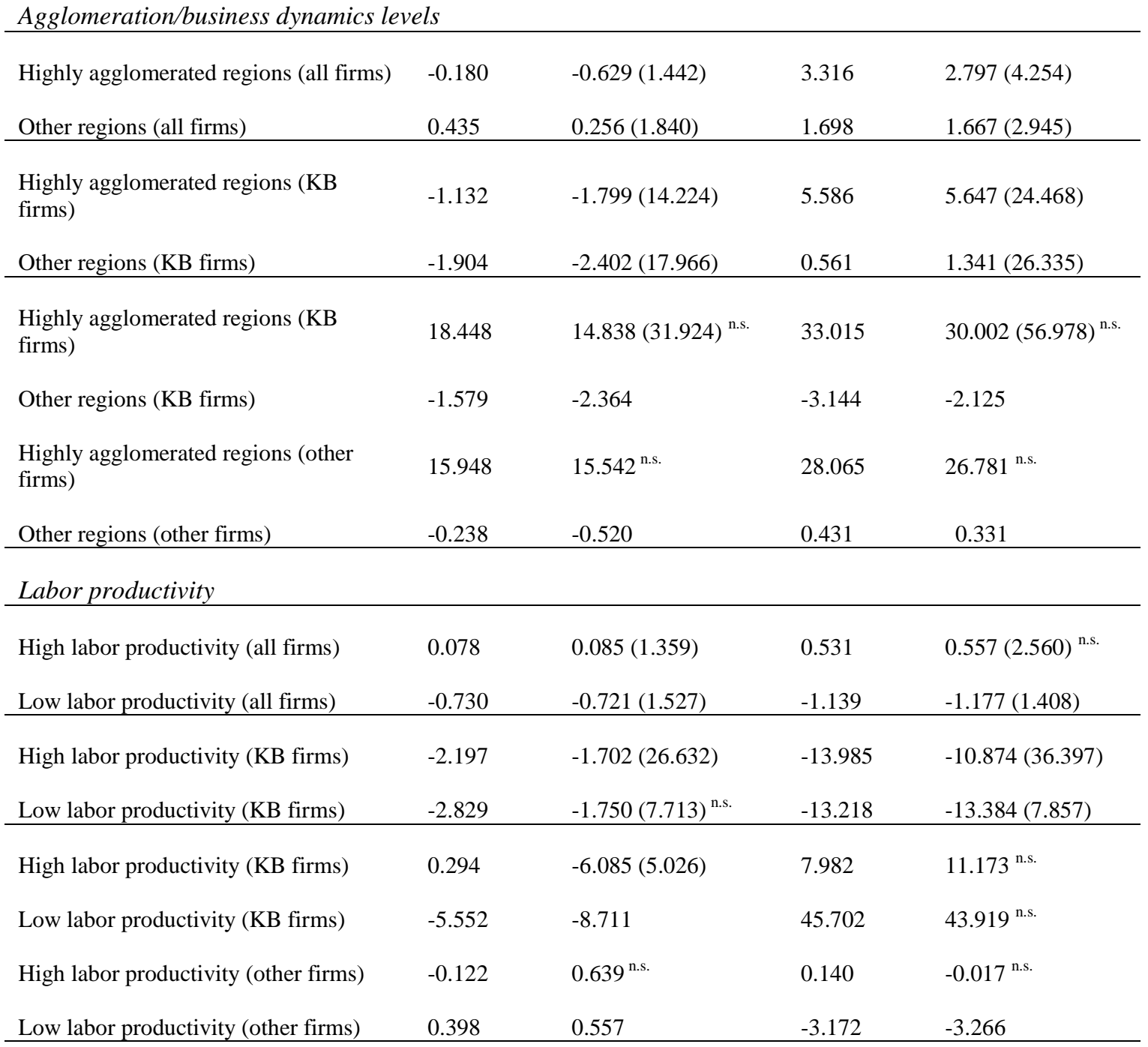

Notes: n.s. $=$ coefficients are not statistically significant at the $10 \%$ level 


\section{Appendix}

Table A1: Portuguese NUTS III regions - population density and start-up rates

\begin{tabular}{llll}
\hline NUTS III & Region Name & Population density & $\begin{array}{l}\text { Average share of } \\
\text { start-ups 1983-2001 (\%) }\end{array}$ \\
\hline 10101 & Minho-Lima & 120 & 2.4 \\
10102 & Cávado & 304 & 4.1 \\
10103 & Ave & 397 & 5.3 \\
10104 & Greater Oporto & 1529 & 12.1 \\
10105 & Tâmega & 211 & 5.3 \\
10106 & Entre Douro e Vouga & 312 & 3.1 \\
10107 & Douro & 63 & 1.5 \\
10108 & Alto Trás-os-Montes & 32 & 1.5 \\
10201 & Baixo Vouga & 208 & 3.1 \\
10202 & Baixo Mondego & 170 & 2.5 \\
10203 & Pinhal Litoral & 138 & 3.0 \\
10204 & Pinhal Interior Norte & 57 & 1.2 \\
10205 & Dão-Lafões & 87 & 2.5 \\
10206 & Pinhal Interior Sul & 29 & 0.4 \\
10207 & Serra da Estrela & 66 & 0.3 \\
10208 & Beira Interior Norte & 31 & 0.9 \\
10209 & Beira Interior Sul & 23 & 0.7 \\
10210 & Cova da Beira & 73 & 0.8 \\
10301 & Oeste & 175 & 4.0 \\
10302 & Greater Lisbon & 1466 & 19.4 \\
10303 & Península Setúbal & 449 & 6.0 \\
10304 & Médio Tejo & 105 & 2.2 \\
10305 & Lezíria do Tejo & 58 & 2.3 \\
10401 & Alentejo Litoral & 20 & 0.9 \\
10402 & Alto Alentejo & 22 & 1.3 \\
10403 & Alentejo Central & 25 & 2.0 \\
10404 & Baixo Alentejo & 18 & 1.4 \\
10501 & Algarve & 73 & 5.5 \\
20101 & R. A. Açores & 110 & 2.1 \\
30101 & R. A. Madeira & 321 & 2.0 \\
\hline & & & \\
\hline
\end{tabular}


Figure A1: Map of Portuguese NUTS III regions by agglomeration/business dynamics levels

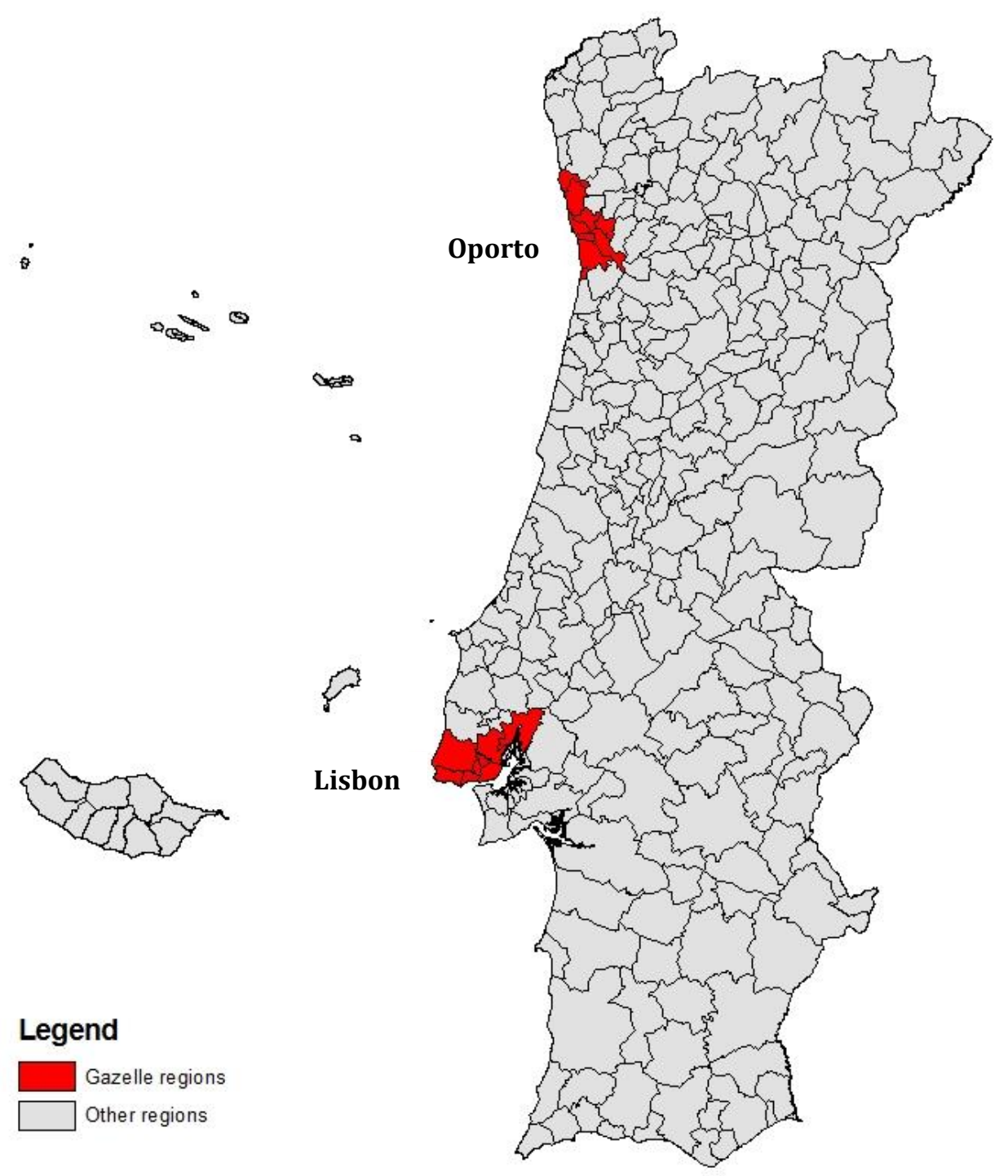

